\title{
GEOLOGICAL AND GEOTHERMAL INVESTIGATION OF THE LOWER WIND RIVER VALLEY, SOUTHWESTERN WASHINGTON CASCADE RANGE
}

\author{
By \\ Dulcy A. Berri \\ Michael A. Korosec
}

1983

Work Performed Under Contract No. AC07-79ET27014

Washington Department of Natural Resources Division of Geology and Earth Resources

Olympia, Washington

Technical Information Center

Office of Scientific and Technical Information United States Department of Energy 


\section{DISCLAIMER}

This report was prepared as an account of work sponsored by an agency of the United States Government. Neither the United States Government nor any agency Thereof, nor any of their employees, makes any warranty, express or implied, or assumes any legal liability or responsibility for the accuracy, completeness, or usefulness of any information, apparatus, product, or process disclosed, or represents that its use would not infringe privately owned rights. Reference herein to any specific commercial product, process, or service by trade name, trademark, manufacturer, or otherwise does not necessarily constitute or imply its endorsement, recommendation, or favoring by the United States Government or any agency thereof. The views and opinions of authors expressed herein do not necessarily state or reflect those of the United States Government or any agency thereof. 


\section{DISCLAIMER}

Portions of this document may be illegible in electronic image products. Images are produced from the best available original document. 


\title{
DISCLAIMER
}

\begin{abstract}
This report was prepared as an account of work sponsored by an agency of the United States Government. Neither the United States Government nor any agency thereof, nor any of their employees, makes any warranty, express or implied, or assumes any legal liability or responsibility for the accuracy, completeness, or usefulness of any information, apparatus, product, or process disclosed, or represents that its use would not infringe privately owned rights. Reference herein to any specific commercial product, process, or service by trade name, trademark, manufacturer, or otherwise does not necessarily constitute or imply its endorsement, recommendation, or favoring by the United States Government or any agency thereof. The views and opinions of authors expressed herein do not necessarily state or reflect those of the United States Government or any agency thereof.
\end{abstract}

This report has been reproduced directly from the best available copy.

Available from the National Technical Information Service, U. S. Department of Commerce, Springfield, Virginia 22161.

Price: Printed Copy A04

Microfiche A01

Codes are used for pricing all publications. The code is determined by the number of pages in the publication. Information pertaining to the pricing codes can be found in the current issues of the following publications, which are generally available in most libraries: Energy Research Abstracts (ERA); Government Reports Announcements and Index (GRA and I); Scientific and Technical Abstract Reports (STAR); and publication NTIS-PR-360 available from NTIS at the above address. 
STATE OF WASHINGTON

DEPARTMENT OF NATURAL RESOURCES

BRIAN J. BOYLE, Commissioner of Public Lands

JAMES A. STEARNS, Department Supervisor

DIVISION OF GEOLOGY AND EARTH RESOURCES

Raymond Lasmanis, State Geologist

GEOLOGICAL AND GEOTHERMAL INVESTIGATION

OF THE

LOWER WIND RIVER VALLEY,

SOUTHWESTERN WASHINGTON CASCADE RANGE

1983

by

DULCY A. BERRI

and

MICHAEL A. KOROSEC

Division of Geology and Earth Resources

Open-File Report 83-5

Prepared under U.S. Department of Energy Contract No. DE-AC07-79ET27014 for assessment of Geothermal Resources in Washington 
CONTENTS

PAGE

Introduction .......................... 1

Previous Work ....................... 3

Regional Geology ....................... 4

Cenozoic Rocks......................... . 5

Introduction ..................... 5

Rocks of the Tertiary Period. . . . . . . . . . . . . . 7

Ohanapecosh Formation. . . . . . . . . . . . . 7

Stevenson Ridge lavas. . . . . . . . . . . . . . . 11

Volcaniclastic or fluvial volcanic sediments . . . . . . . 13

Yakima Basalt Subgroup ................... 15

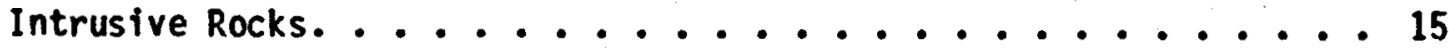

Associated andesite flows. ............... 19

Coarse pyroclastic flows ................... 20

Coarse clastic breccia .................. . . 20

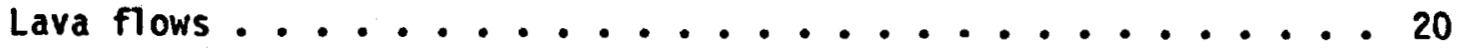

Quaternary Rocks........................ 21

Trout Creek basalt ...................... 21

Quaternary sediments ..................... 23

Summary of Rock Units and Stratigraphy. . . . . . . . . . . 23

Geologic Structures. . . . . . . . . . . . . . . . . 24

Geochemistry ........................ 27

Subsurface Geology . . . . . . . . . . . . . . . . 34 


\section{CONTENTS (CONT'D)}

Evaluation of Geothermal Resource Potential. . . . . . . . . 36 Setting ...................... 36

Nature of the Thermal Water and Heat Source . . . . . . . . . 38

Geothermal Resource ..................... . 4 42

Summary and Conclusions. . . . . . . . . . . . . . . . 43

Acknowl edgments. . . . . . . . . . . . . . . . . 46

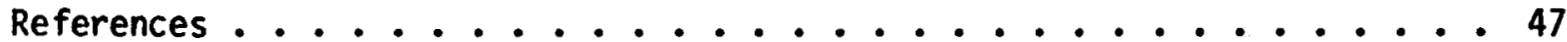


PAGE

Figure 1. Location of Wind River, southwestern Washington

Cascade Range. Study area outlined. . . . . . . . 2

2. Stratigraphic columns for this study and from previous work by Wise (1970) and Hammond (1980) . . . . . . . 6

3. Generalized composite columnar section, Wind River valley, southwest Washington ............. 8

4. Intrusions of the lower Wind River valley: . . . . . . 16

5. Relationships of intrusive bodies (shaded) and hot springs to structures, Lower Wind River valley . . . . . . 25

6. Variation diagrams for major oxides versus silica in Lower Wind River rocks............... . 31

7. Lithologic logs of drill holes, Lower Wind River valley...................... 35

8. Temperature versus depth diagram for DNR-8 and Hegewald well .....................

\section{LIST OF TABLES}

Table 1. K-Ar Radiometric age dates, Lower Wind River valley........................ 12

2. Modes of intrusive rocks . . . . . . . . . . . . 17

3. Chemical analyses of Tertiary lavas and volcaniclastic rocks..................... 28

4. Chemical analyses of intrusive rocks . . . . . . . . 29

5. Chemical analyses of Trout Creek Basalt . . . . . . . 30

6. Characteristics of two Wind River hot springs . . . . . 39 


\section{INTRODUCTION}

The Wind River valley, on the west slope of the Cascade Range, is a northwest-trending drainage that joins the Columbia River near Carson, Washington (figure 1). The region has been heavily dissected by fluvial and glacial erosion. Ridges have sharp crests and deep subsidiary valleys typical of a mature topography, with a total relief of as much as $900 \mathrm{~m}$. The region is vegetated by fir and hemlock, as well as dense, brushygroundcover and undergrowth.

The lower $8 \mathrm{~km}$ of the valley is privately owned and moderately populated. The upper reaches lies within the Gifford Pinchot National Forest, and include several campgrounds and day parks, the Carson National Fish Hatchery, and the Wind River Ranger Station and Wind River Nursery of the U.S. Forest Service. Logging activity is light due to the rugged terrain, and consequently, most valley slopes are not accessible by vehicle.

The realization that a potential for significant geothermal resources exists in the Wind River area was brought about by earlier exploration activities. Geologic mapping and interpretation was needed to facilitate further exploration of the resource by providing a knowledge of possible geologic controls on the geothermal system. This report presents the detailed geology of the lower Wind River valley with emphas is on those factors that bear significantly on development of a geothermal resource.

The limits of the study area shown in figure 1 were determined by the locations of potential geothermal energy users. Thus the area covers the Wind River valley from the town of Carson north as far as Trout Creek Hill. Geothermal systems which may exist outside of this area, especially 


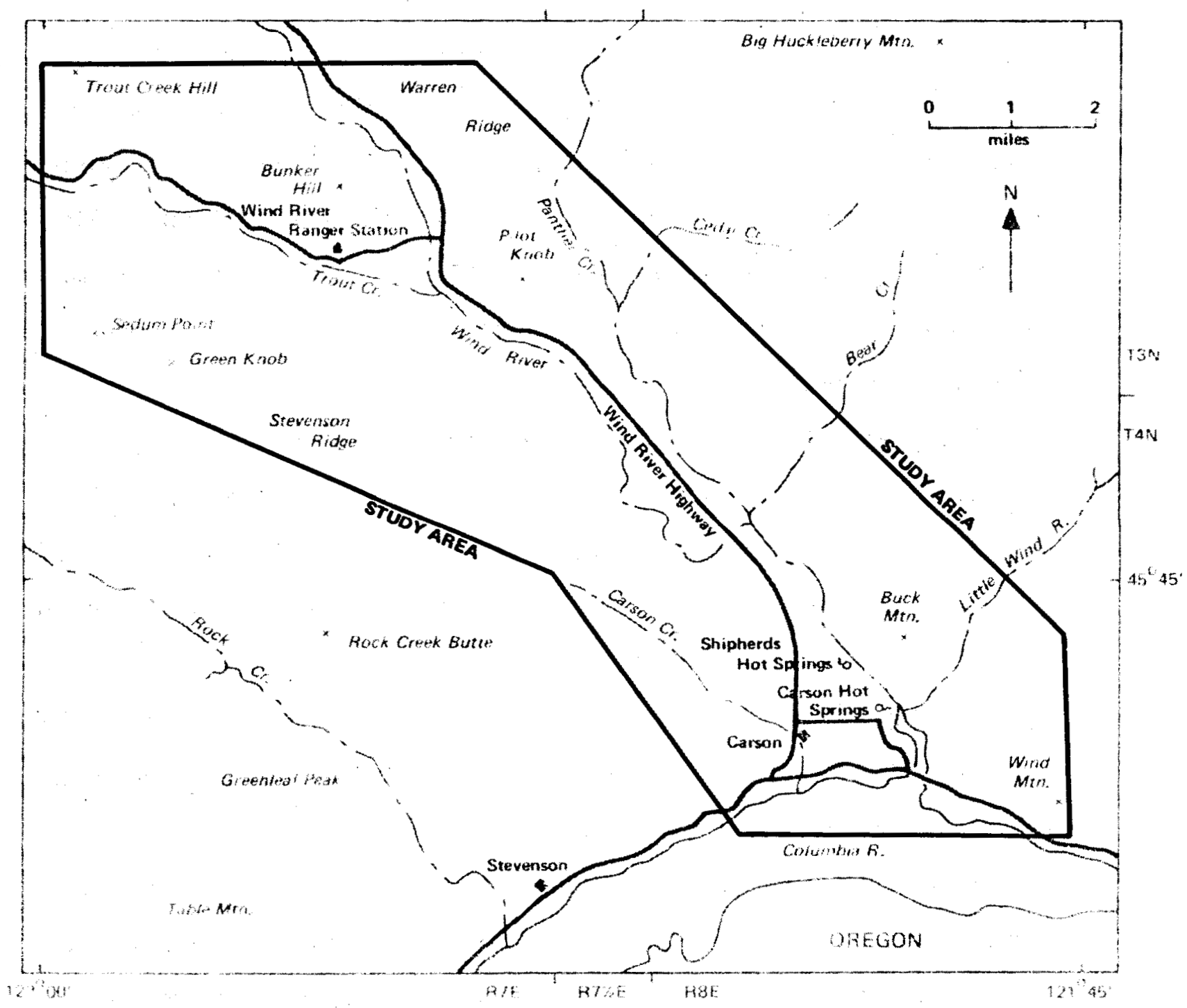

Figure 1. Location of Wind River, southwestern Washington Cascade Range. Study area outlined. 
within the National Forest to the north, will have to produce high temperature resources in order to be considered for near term future use because of the distance from potential users.

\section{PREVIOUS WORK}

Prior to Forest Service road improvements in the region, the Wind River area was studied only at the southern end of the valley, near its confluence with the Columbia River. Geologic reconnaissance in the vicinity north and south of the Columbia River includes work by Williams (1916), Chaney (1918), Allen (1932), and Hammond (1980).

A detailed investigation by Wise (1961, 1970) extended over $30 \mathrm{~km}$ north of the Columbia River into the Quaternary lava plateau which forms the Wind River headwaters. Wise described the stratigraphy and petrology of Cenozoic basaltic and andesitic lavas, tuff, and tuff breccia, volcaniclastic sediments, and intrusive bodies. Additional study of intrusive rocks by Free (1976) compared Wind River diorites to other intrusives in the Columbia River Gorge.

The most recent work in the Wind River area was conducted by the Washington Department of Natural Resources, Division of Geology and Earth Resources (DNR) from 1980 to 1982. Thermal and mineral springs were sampled and analyzed and two temperature gradient test holes were drilled. One hole was located near the Carson Hot Springs at the south end of the valley (DNR-8). The other hole was drilled near the Wind River Ranger Station (DNR-7), about $7 \mathrm{~km}$ northwest of DNR-8. Water temperatures of $53^{\circ} \mathrm{C}$ exist at the Carson Hot Springs, and the nearby drill hole has a gradient of $366^{\circ} \mathrm{C} / \mathrm{km}$. DNR-7, to the northwest, has a temperature gradient of $84^{\circ} \mathrm{C} / \mathrm{km}$. 
REGIONAL GEOLOGY

The Cascade Range experienced volcanism from the early Tertiary through Quaternary Periods. Eocene to early Pliocene rocks form the bulk of the Cascade Range in southwestern Washington (Hammond, 1980).

01 igocene volcanic rocks in the Mount Rainier area were assigned to the Ohanapecosh Formation by Fiske and others (1963). This includes andesitic and basaltic lavas and volcaniclastic rocks that are thought to have filled a submerged basin initially, and later were deposited subaerially. Late 0ligocene to Miocene volcanism north of the Wind River area was increasingly silicic, including pyroclastic flows, volcaniclastic rocks, and pyroxene andesite and basalt flows, in order of relative volumes. From the east, the Miocene Yakima Basalt Subgroup of the Columbia River Basalt Group flowed across the southeast part of the Wind River area. High-alumina olivine basalt was the dominant volcanic rock in the late Tertiary and Quaternary Periods. The basalt erupted from numerous volcanoes within the Cascade Range, including Trout Creek Hill, Rock Creek Butte, and Cedar Creek in or near the study area (figure 1). Northeast of the study area, the basaltic lava flows coalesced to form a plateau called Indian Heaven. The Quaternary period was also marked by the formation of several large, scattered, andesitic stratovolcanoes, including Mount St. Helens, Mount Adams and Mount Rainier.

Regional structures influencing the geology of the Wind River area include two super-imposed fold trends and two directions of faulting. Tertiary strata are folded along a northwest trend with gently to moderate dips. This trend may be parallel to the northwesterly Mesozoic structural grain of the North Cascades (Hammond, 1980). Superimposed on these folds 
are northeast-trending folds related to the Pliocene Yakima folds (Hammond, 1980).

A northwest-trending fault system in the region probably accompanied development of the northwest-trending folds. North-south trending faults in the southern Washington Cascade Range reflect east-west extension within the range. Examples of this include the north-south trending Indian Heaven and King Mountain fissure zones (Hammond, 1980).

\section{CENOZOIC ROCKS}

Introduction

The oldest exposed unit in the Wind River area is the Ohanapecosh Formation (figure 2). The unit is at least $5000 \mathrm{~m}$ thick in southern Washington and is generally composed of volcaniclastic deposits, lava flows, and pyroclastic flows. It has been mapped across the southern Washington Cascade Range as representing a time of primarily distal, andesitic volcanism (Fiske, 1963; Fiske and others, 1963).

West of the Wind River, the Ohanapecosh Formation is unconformably overlain by Stevenson Ridge lavas. These basaltic-andesites correlate with the Three Corner Rock lavas of Hammond (1980), believed to be late 01 igocene-early Miocene in age.

Another late 01 igocene-early Miocene volcanic unit common in the south Cascades is the Stevens Ridge Formation. These dacitic pyroclastic flows and minor andesite flows have been mapped to the north and east of the study area by Hammond (1980). The Stevens Ridge Formation is either not present in the lower Wind River valley, or is not distinguishable from upper Ohanapecosh strata. 


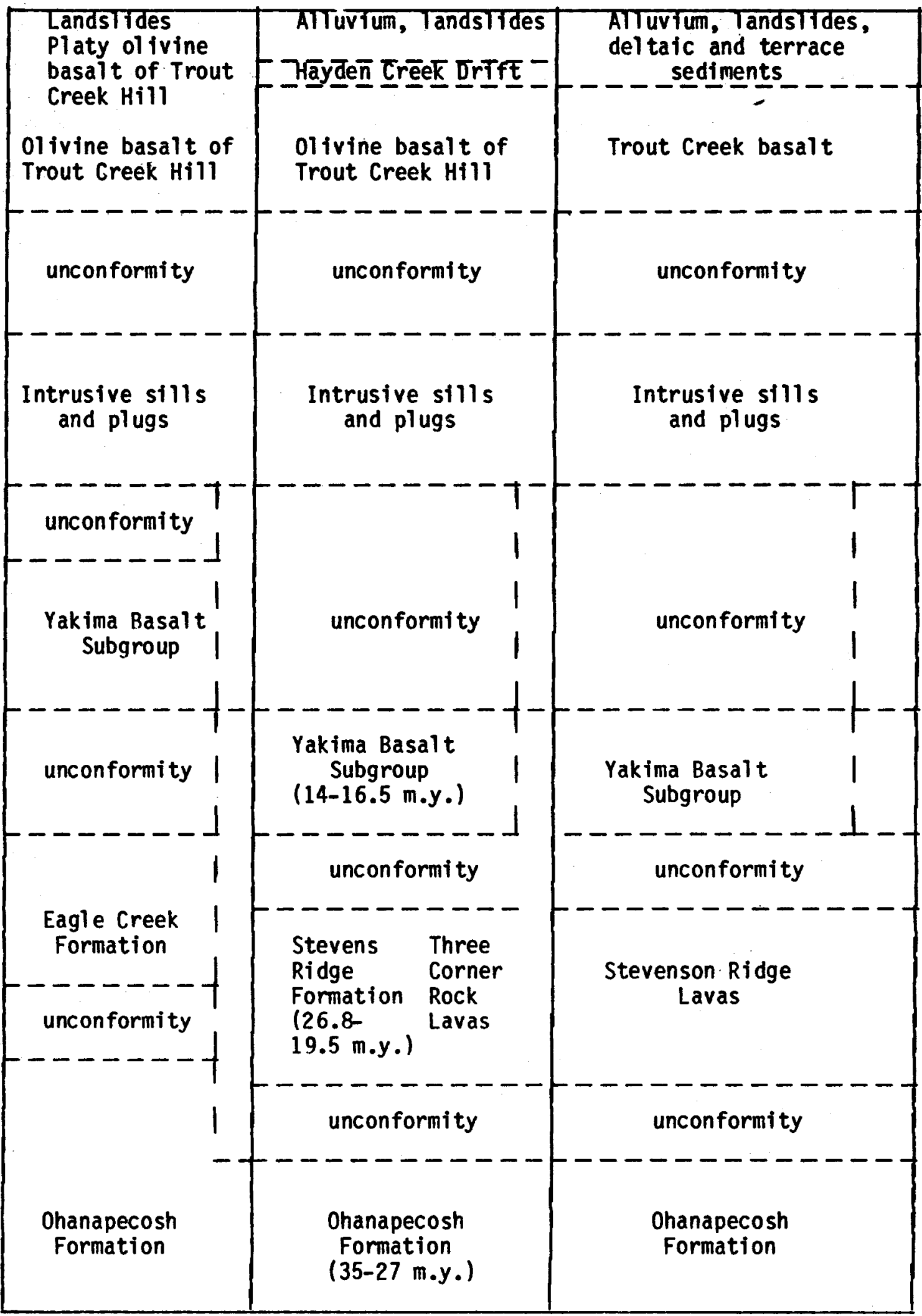

Figure 2. Stratigraphic columns for this study and from previous work by Wise (1970) and Hammond (1980). 
Wise (1970) assigned the Stevenson Ridge andesite flows to the upper Ohanapecosh Formation (figure 2). Radiometric age dates, however, indicate that the andesite is considerably younger than the Ohanapecosh Formation.

Miocene Yakima Basalt flows entered only the extreme southeast corner of the Wind River valley and were subsequently intruded by quartz diorite of Wind Mountain. Intrusive events generally occurred from the Miocene through the Pliocene. Quaternary olivine basalt of Trout Creek Hill is the most recent volcanism in the lower Wind River valley.

Rocks of the Tertiary Period

Ohanapecosh Formation. The oldest exposed rocks in the Wind River area are assigned to the Ohanapecosh Formation (Wise, 1970; Waters, 1973; Hammond, 1980). The formation has been age-dated at 35 to 27 m.y. in several portions of the Cascades beyond the study area (Hammond 1980). In the Ohanapecosh Formation of the lower Wind River valley, lava and pyroclastic flows are minor in comparison to volcaniclastic rocks (figure 3). In contrast, Wise (1961) reported a 600-900 $\mathrm{m}$ section of Ohanapecosh breccias and flows about $14 \mathrm{~km}$ to the north, with a high percentage of lavas. The Ohanapecosh Formation within the study area, may represent products of distal volcanism in which volcanic centers were located outside of the area and the bulk of volcanic materials are volcaniclastic in origin.

The base of the Ohanapecosh Formation is not exposed in the Wind River valley. The formation has a total thickness of at least $400 \mathrm{~m}$, as exposed on the east side of the valley, from riverbed to ridgetop between Jimmy Creek and Bear Creek. 


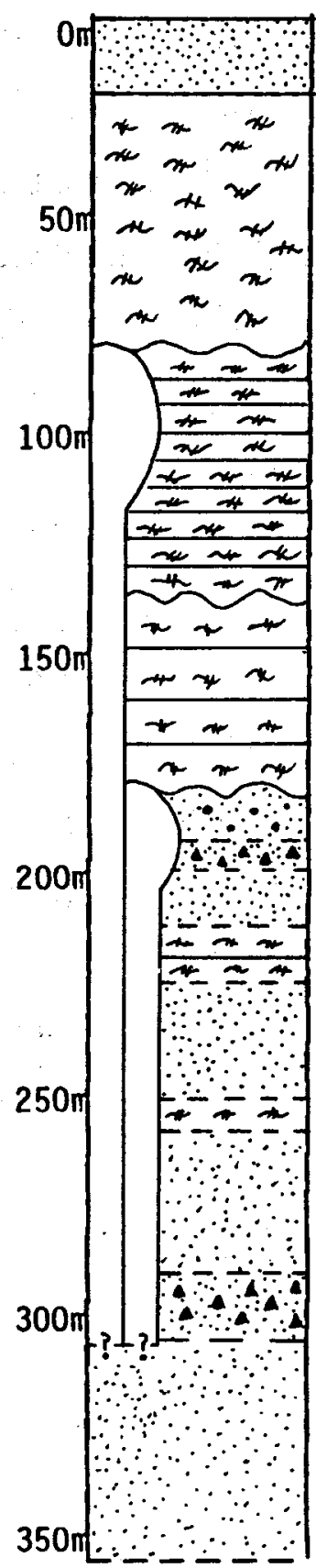

Recent sediments - alluvium, lands Tide debris, del taic and ter.race deposits.

Trout Creek basalt - $(70 \mathrm{~m})$ grey, diktytaxitic olivine-rich basalt, not separable into distinct flows, probably erupted continuously over a short time interval.

Yakima Basalt, Grande Ronde Member $(50 \mathrm{~m}$ ?) black sparsely phyric basalt, unknown thickness; in southeast corner of area in slide contact with . Ohanapecosh Formation.

Stevenson Ridge Lavas - $(30 \mathrm{~m})$ pyroxene andesite flows, overlie deeply weathered zone in Ohanapecosh

Ohanapecosh Formation - (at least 300m) primarily volcaniclastic sediments with minor interbedded pyroclastic flow and mudflow deposits of tuff breccia and minor andesite and basalt intracanyon flows.

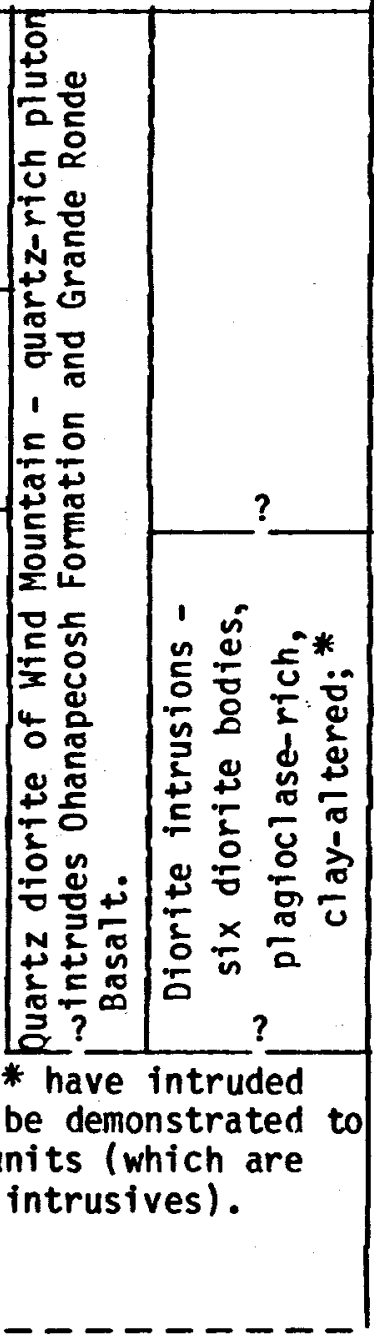

Figure 3. Generalized composite columnar section, Wind River valley, southwest Washington. 
The high degree of mineral alteration in all subunits of the Ohanapecosh Formation attests to the significant hydrothermal al teration and deep weathering experienced by these materials. Lavas exhibit groundmass al teration to yellowish-green clays or chlorite, pyroxene replacement by clay, and slight zeolitization of plagioclase. Fragmental volcanic subunits are pervasively altered to yellowish-brown and green clays and chlorite. Pumice clasts and glass shards are completely altered to a fine, yellowish-brown, highly birefringent mineral. Zeolites fill fractures and pore spaces and replace glass. Concentrations of zeolite and silica occur in sediments near diorite intrusions and were formed by localized heating of connate water within Ohanapecosh sediments during emplacement of the intrusions. Oxidation of iron released by mineral breakdown in porous breccias resulted in hematite-coated clasts.

The unconformity at the top of the Ohanapecosh Formation on Stevenson Ridge indicates prolonged chemical weathering that produced a thick layer. of montmorillonite. Abundant higher-temperature smectite, chlorite, and zeolite minerals, however, indicate pervasive hydrothermal al teration has occurred. This alteration may represent low-grade regional metamorphism that developed during formation of northwest-trending folds across the southern Washington Cascades during the Miocene (Hammond, 1977). Continuous or several stages of deformation may have occurred after Miocene time, but pervasive hydrothermal alteration is not observed in postOhanapecosh strata.

A porphyritic pyroxene dacite crops out on the lower flanks of northern Stevenson Ridge directly west of the Hemlock Ranger Station (plate I). The dark grey to black dacite is platy and blocky-jointed. Highly wea thered outcrops average about $3 \mathrm{~m}$ thick. 
A K-Ar age date for the dacite was determined to be $22.7 \pm 0.3$ m.y., far younger than anticipaied for a unit of the Ohanapecosh Formation. The discrepancy may be due to several possibilities, including misassignment of this flow to the Ohanapecosh Formation or thermal resetting of the $\mathrm{K}-\mathrm{Ar}$ clock. The flow was assigned to the Ohanapecosh Formation because it is overlain and underlain by volcaniclastics similar to material on the east side of the valley, and because both the flow and volcaniclastics show the same degree of alteration. However, the dacitic composition of the flow is in contrast with the more basic andesites and basalts which characterize the Ohanapecosh Formation in this portion of the south Cascades. The radiometric age of the dacite is very close to the age determined for the diorite of Warren Ridge, at $23.2 \pm 1.0 \mathrm{~m} . \mathrm{y}$. It is quite possible that the intrusive activity associated with the Warren Ridge event and/or regional low-grade zeolite facies metamorphism during the Miocene reset the $K$-Ar values.

The proper solution to this problem would require additional work, including resampling and analysis, but in this report, it is assumed that the dacite flow is a high silica upper unit of the Ohanapecosh Formation which has had its $K-A r$ date thermally reset. (See sample 2 in tables 1 and 3 ).

01 igoclase andesite occurs high on the divide between Bear Creek and Brush Creek. The exposure is $122 \mathrm{~m}$ long by $30 \mathrm{~m}$ thick, with poorly developed columnar jointing. Yellow granular clay is pervasive, and chloritic masses occur in scattered lenses about $2 \mathrm{~cm}$ long.

An aphyric basalt of very limited extent caps Huckleberry Ridge and is less than $3 \mathrm{~m}$ thick. Platy joints dip to the southwest. 
Identification of clay and zeolite minerals was performed by Wise (1961). The most common zeolite minerals are heulandite, laumontite, and analcite. The association of these minerals with other hydrothermal minerals allowed Wise to fix the maximum temperature of alteration at $280^{\circ} \mathrm{C}$ with pressure of 1000 bars.

The abundant birefringent, yellowish-brown mineral showed $X$-ray diffraction properties intermediate between saponite (a variety of smectite) and chlorite. Wise labeled the clay "griffithite", an ironrich saponite. A random mixed-layer saponite-chlorite has been found in rocks of similar lithologies and age in the Mount Hood area. It grades into chlorite at increasing temperature and depth with the transition to chlorite being complete at about $180^{\circ} \mathrm{C}$ (Holdaway and Bussey, 1982). Because saponite-chlorite coexists with chlorite in Wind River rocks, thermal metamorphism did not exceed $180^{\circ} \mathrm{C}$, assuming a single metamorphic event.

Stevenson Ridge lavas. Porphyritic pyroxene basaltic-andesite and lesser amounts of basalt form the crest of Stevenson Ridge (plate I). Flows are flat-lying or dipping very gently westward. The east margin of the lavas suggests that they may have flowed southeastward toward the Columbia River, crossing the present-day valley south of Carson, perhaps flowing through a paleodrainage. Stevenson Ridge would therefore represent inverted topography and an ancient course of the Wind River.

A date of $15.7 \pm 1.5$ m.y. (table 1) was obtained from southeast Stevenson Ridge. The basaltic-andesite is believed to correlate with andesite of Three Corner Rock to the west, suggested by Hammond (1980) to be of late 01 igocene-early Miocene age. If the flows drained to the south or southeast, this dated material may underlie younger flows found higher on the ridge to the north. 
TABLE 1.

\section{K-Ar Radiometric Age Dates, Lower Wind River Valley}

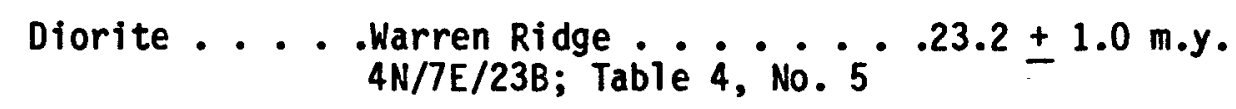

Basaltic-

Andesite. - . . Stevenson Ridge lava . . . 15.7 \pm 1.5 m.y. 3N/8E/18D; Table 3, No. 13

Analyst: Stanley Evans, University of Utah Research Institute

Dacite . . . Ohanapecosh Formation. . . $22.7 \pm 0.3$ m.y. Basalt . . . Trout Creek basalt . . . 0.338 + $0.075 \mathrm{~m} \cdot \mathrm{y}$; $(338,000 \pm 75,000)$

Analyst: R. A. Duncan, Oregon State University 
Stevenson Ridge to the west contains gently dipping Ohanapecosh sediments, lavas, and tuff breccias between the valley floor and about the $730 \mathrm{~m}$ elevation, for a total thickness of $280 \mathrm{~m}$. The contact with overlying Stevenson Ridge lavas appears to dip gently to the southsoutheast. The contact is an erosional unconformity.

The following three subunits were differentiated within the Ohanapecosh Formation: 1) fine-grained volcaniclastic sediments, 2) massive pyroclastic flows and volcanic breccias, including mudflows, and 3) lava flows. Plate I indicates the extent of these subunits. Undifferentiated Ohanapecosh Formation is used only where subunits cannot be shown separately at this map scale.

Volcaniclastic or fluvial volcanic sediments are the most abundant of the Ohanapecosh subunits. Generally well-sorted, dark reddish-brown, Iithified sediments consist of rounded andesite and altered pumice particles, less than $2 \mathrm{~cm}$ in size. The matrix is altered glass, crystals, clay, and organic grains. Some strata consist entirely of opaque organic material. Secondary replacement of the matrix has occurred in isolated areas, consisting of silica and zeolite. Numerous thin zeolite veins occur in sediments around Buck Mountain.

Within the study area, most slopes are heavily vegetated and rock exposures are extremely limited. In many cases, lack of outcrops of the more coherent tuff breccia or lava outcroppings implied the presence of nonresistant, fine-grained sediments that have weathered back, forming a thick soil cover. 
At the north end of Stevenson Ridge, dark grey pyroxene basalticandesite nearly $30 \mathrm{~m}$ thick caps the ridge. Platy joints grade upward into blocky jointing. Groundmass feldspar microlites show slight alignment. Labradorite phenocrysts have cores of smectite or scattered sericite. Light green, anhedral augite occurs in the groundmass and as phenocrysts. Contorted platy-jointed pyroxene basaltic-andesite on the east side of Stevenson Ridge, west of Carson, is dense and nonvesicular. It forms a dip slope, and in many places is found in landslide deposits over weathered Ohanapecosh Formation. It is very similar petrographically to basalticandesite to the north. Basaltic-andesite also occurs along the Columbia River south of Carson, underlying olivine basalt from Trout Creek Hill. At these two locations, volcanic flow-breccia contains deuteric fracture coatings and veins of clay and silica. This flow breccia indicates the terminus of the andesite flow(s) was south of Carson, near or at the Columbia River.

Dark gray to black aphyric basalt occurs east of Sedum Point at the extreme west edge of the study area. The basalt averages $10 \mathrm{~m}$ thick and extends westward an unknown distance. Its relationship to other basalts in the area is unclear. The densely aphyric basalt was found in places to contain megascopic feldspar phenocrysts and patches of dark green clayey alteration. It is similar to Grande Ronde Basalt occurring across the valley northeast of Wind Mountain, and is quite distinct from the nearby olivine basalt of Trout Creek Hill (described below). It was mapped as a separate unit, but it could be a subunit of the Stevenson Ridge lavas or a remnant of Columbia River Basalt. 
Yakima Basalt Subgroup. Basalt of the Grande Ronde Basalt Formation, Yakima Basalt Subgroup, Columbia River Basalt Group, occurs in the extreme southeast part of the Wind River valley, northeast of Wind Mountain. The unit is widespread east of Wind Mountain and forms ridgetops north and west of the Bonneville landslides to the west. The Grande Ronde Basalt has been age dated at 14 to $16.5 \mathrm{m.y}$. old (Hammond, 1980).

The basalt is sparsely porphyritic, containing feldspar and pyroxene as phenocrysts and groundmass grains. Nearly $40 \%$ of the rock consists of black opaque glass with magnetite.

The Wind Mounta in landslide, east of Wind Mountain, consists of basalt and other rock debris actively sliding over a base of weak montmorillonite clay of the Ohanapecosh Formation (Pope, 1972). The large inactive slide north and west of Wind Mountain (Plate I) also consists of basalt with volcaniclastic debris that has slipped along a zone of weathered green clay. It is possible then, that the Grande Ronde Basalt was deposited over a deeply weathered Ohanapecosh surface similar to that underlying the slightly older andesite of Stevenson Ridge, a surface that encourages slippage of the dense lavas.

Intrusive rocks. Many sills and plugs intruded rocks of the Ohanapecosh Formation. Six distinctive intrusions are named and identified, all lying along the Wind River valley (figure 4). Modal compositions show petrographic distinctions (table 2 ).

The quartz diorite of Wind Mountain forms a promontory $580 \mathrm{~m}$ above sea level along the Columbia River, just east of the confluence with the Wind River. The plug has a diameter of roughly $1.2 \mathrm{~km}$ at its base. The light grey holocrystalline diorite contains plagioclase phenocrysts, 


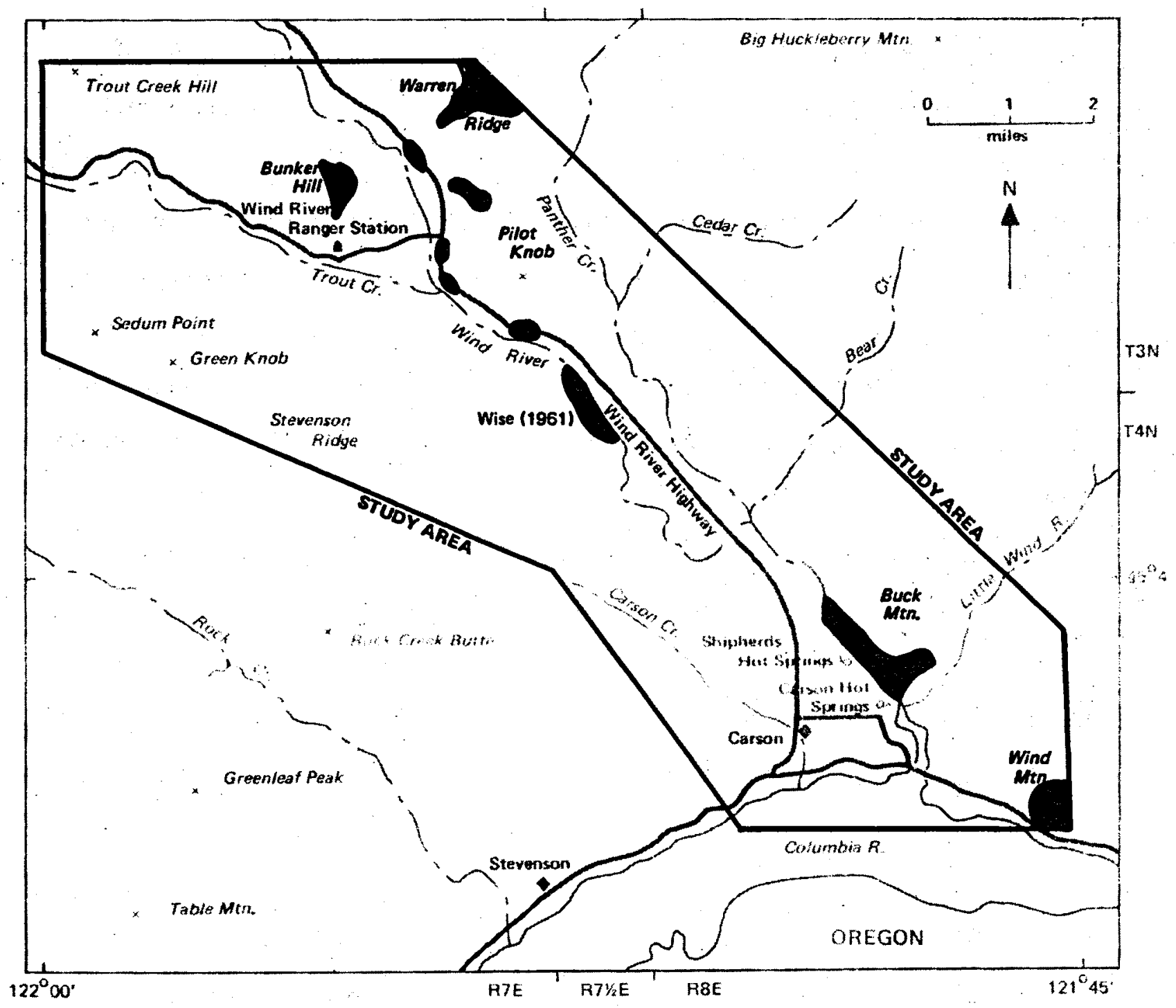

Figure 4. Intrusions of the lower Wind River valley: Wind Mountain - quartz diorite; Buck Mountain, Wise (1961), P.ilot Knob, Warren Ridge diorite; Bunker Hill - gabbro. 
TABLE 2

MODES OF INTRUSIVE ROCKS

\begin{tabular}{|c|c|c|c|c|c|c|c|}
\hline & $\begin{array}{l}\text { Wind Mtn. } \\
\text { quartz diorite }\end{array}$ & $\begin{array}{l}\text { Buck Mtn. } \\
\text { diorite }\end{array}$ & $\begin{array}{r}\text { Pilot Kno } \\
\text { south body }\end{array}$ & $\begin{array}{l}\text { b diorite } \\
\text { west body }\end{array}$ & $\begin{array}{r}\text { Warre } \\
\text { dic }\end{array}$ & & $\begin{array}{c}\text { Bunker } \mathrm{Hfll} \\
\text { gabbro }\end{array}$ \\
\hline Sample No. & WM-4 & WR-13 & WR-T & WR-1 & PK-I & WAR-4 & BH-1 \\
\hline $\begin{array}{l}\text { Phenocrysts: } \\
\text { plagiocl ase } \\
\text { augite } \\
\text { hypersthene }\end{array}$ & $\begin{array}{l}12^{\star} \\
<1\end{array}$ & $\begin{array}{l}7 \text { An40 } \\
<1\end{array}$ & & . & $<1^{\star}$ & & $\begin{array}{l}<1^{*} \\
<1\end{array}$ \\
\hline $\begin{array}{l}\text { Groundmass: } \\
\text { plagiocl ase } \\
\text { pyroxene } \\
\text { magnetite } \\
\text { apatite } \\
\text { quartz }\end{array}$ & $\begin{array}{l}47 \mathrm{An}_{38} \\
23 \\
9 \\
<1\end{array}$ & $\begin{array}{l}68 \text { An }_{62} \\
13 \\
4 \\
1\end{array}$ & $\begin{array}{c}76 * \\
10 \\
5 \\
<1\end{array}$ & $\begin{array}{l}70 \text { An }_{20} \\
10 \\
7\end{array}$ & $\begin{array}{l}45 \text { An }_{34} \\
12 \\
7 \\
2 \\
<1\end{array}$ & $\begin{array}{l}67 \operatorname{An}_{48} \\
14 \\
4 \\
<1 \\
<1\end{array}$ & $\begin{array}{l}67 \text { An } 46 \\
6 \\
5\end{array}$ \\
\hline $\begin{array}{l}\text { Al teration: } \\
\text { biotite } \\
\text { clays } \\
\text { augite } \\
\text { calcite }\end{array}$ & $\begin{array}{r}<1 \\
8\end{array}$ & $\begin{array}{l}6 \\
<1 \\
<1\end{array}$ & 8 & $\begin{array}{l}5 \\
8\end{array}$ & 34 & 14 & 22 \\
\hline
\end{tabular}

* An content of plagioclase not determinable due to heavy al teration and/or zoning. 250 points counted per sample. 
subporphyritic hornblende pseudomorphs, granular cryptofelsitic material, and magnetite. Biotite and magnetite have. replaced hornblende phenocrysts, and the plagioclase has been intensely sericitized.

Wise (1961) describes an intrusive contact of the quartz diorite with Miocene basalt, supported by the presence of basaltic xenoliths in the diorite (Free, 1976). Consequently, the Wind Mountain intrusion is younger than the Grande Ronde Basalt, younger than about 14 m.y. (Hammond, 1980).

The Wind River fishway sill and Buck Mountain intrusion, treated by Wise (1961) as separate bodies, are believed to be irregularly exposed portions of a continuous mass referred to here as the Buck Mountain intrusion (figure 4). The intrusion is exposed for about $3.2 \mathrm{~km}$ along the Wind River east of Carson, forming the steep west and south flanks of Buck Mountain. Exposures on south Buck Mountain are higher in elevation than those to the northwest, suggesting a northwest-dipping intrusion (plate I; plate II, cross-section $\left.B-B^{\prime}\right)$. The diorite is light grey to bluish-grey, and contains large plagioclase phenocrysts, zone $\mathrm{An}_{10-50}$, with minor calcite replacement of cores. Hypers thene phenocrysts are included and embayed, most often by augite. Clay alteration of pyroxene, similar to the celadonite of Wise (1961), is common.

Two diorite bodies occur at Pilot knob. The southwest flank of the hill contains a well-exposed diorite sill, about $12 \mathrm{~m}$ thick, that has upwarped the overlying tuff breccia of the Ohanapecosh Formation. Equigranular feldspar $\left(A n_{15-25}\right)$ and augite are included and embayed, and the augite is commonly replaced by hornblende and magnetite. Near the contact, the intrusion contains pods and lenses of silica with granular and fibrous zeolites. 
A highly altered, trachytic quartz-bearing diorite occurs on the south flank of Pilot Knob and is more siliceous than other diorite bodies at Pilot Knob. It may be related to a sill located about $1.6 \mathrm{~km}$ to the southeast along the Wind River. Formidable access problems inhibited sampling of this latter sill, mapped by Wise (1961) and included on plate I.

The northern Pilot Knob intrusion (see figure 4; PK-1, table 2) is closely related to a diorite body that underlies Warren Ridge to the north (WAR-4, table 2). Nearly equigranular pilotaxitic feldspar is zoned and heavily replaced by yellowish-orange clays. Ophitic granular augite is replaced by similar clays. A higher degree of clay alteration is evident in PK-1, in contrast to WAR-4. Chemical analyses show these rocks to have very similar major element compositions. Diorite of Warren Ridge was dated at $23.2 \pm 1.0 \mathrm{~m} . y$. (table 1 ); al though it post-dates Ohanapecosh Formation, it does not appear to be significantly younger, as indicated by its highly altered condition.

Very dark and coarse-grained intrusive rock of gabbroic composition forms Bunker Hill, west of Pilot Knob. Massive blocky outcrops are found on the south and southeast flanks. The gabbro consists of euhedral feldspar phenocrysts $\left(\mathrm{An}_{46}\right)$ and subhedral augite, both altering to celadonite. The groundmass contains anhedral zoned feldspar, magnetite, and pyroxene, with significant clay alteration. Wise (1961) estimated the age of the Bunker Hill intrusion to be post-lower Miocene.

Associated andesite flows. Hornblende andesite forms the cap rock of Warren Ridge at the northeast corner of the study area. Wise (1961) interpreted this to be a diorite sill. However, vesicularity and outcrop locations suggest the andesite is a ridge-capping lava derived from diorite plug material exposed on the lower flanks. The lava and plug are similar petrographically and chemically. 
Coarse pyroclastic flows of the Ohanapecosh Formation are best exposed in the Bear Creek area. Wise $(1961,1970)$ presented detailed lithologic sections of massive tuff breccias averaging $11 \mathrm{~m}$ thick, with interbedded finer-grained tuff, sandstone, conglomerate, or claystone. The massive and poorly-sorted lithic and pumice-rich iuff breccias were interpreted as pyrociastic flow units.

Coarse clastic breccia outcrops are widespread in the Wind River valley. Outcrops are rounded by weathering and form discontinuous exposures of green, grey, or reddish-brown breccia 8 to $15 \mathrm{~m}$ thick. Clasts of andesite, basalt, and pumice are very poorly sorted, ranging in size from $2 \mathrm{~cm}$ to $0.5 \mathrm{~m}$. The matrix generally includes brown and green clay with silt-sized lithic fragments and altered glass shards, and commonly contains hematite and fine-grained plagioclase and augite crystals. Prismatic zeolite was observed in cavities replacing green and brown clay. Rare carbonized wood fragments were found, as well as thin interbeds of fine to medium-grained sands tone. The lack of sorting among angular and rounded clasts indicates deposition of these strata by lahars and/or debris flows.

A tuff breccia occurs at the top of the Ohanapecosh Formation on Stevenson Ridge. The ol ive to blue-green colored rock has been intensely weathered to olive-colored clay. The weathered zone extends downward in the breccia for about $3 \mathrm{~m}$. This unconformity acts as a slide plane for the overlying Stevenson Ridge lavas (plate I).

Lava flows of the Ohanapecosh Formation are up to $30 \mathrm{~m}$ thick, and are primarily composed of discontinuous, highly weathered and altered andesite and basalt. The lavas cannot be traced laterally for any distance.

A porphyritic pyroxene dacite crops out on the lower flanks of northern Stevenson Ridge directly west of the Hemlock Ranger Station (plate I). The dark grey to black dacite is platy and blocky-jointed. Highly weathered outcrops average about $3 \mathrm{~m}$ thick. 
The flow is at least $30 \mathrm{~m}$ thick, with irregular platy jointing and zones of vesicularity. Hornblende pseudomorphs are composed of granular magnetite with pyroxene rims and cores. The cryptofelsitic groundmass contains abundant apatite.

Hydrothermal alteration is pervasive in all diorites of the Wind River valley. Most common are sericitized calcic cores of plagioclase grains. Calcite also has replaced some plagioclase. Pyroxene was susceptible to alteration to a montmorillonoid clay. Amphibole commonly replaced augite, and less commonly was itself altered to biotite and magnetite.

The alteration may have been achieved through two processes: 1) during the late stages of crystallization, minerals may form at the expense of earlier formed minerals (react with remaining melt), such as augite jacketing hypersthene, or 2) a separate, post-crystallization event of metasomatic metamorphism may cause ionic transfer and al teration of mineral compositions, as in uralitization of pyroxene to form hornblende and magnetite. Unfortunately, both processes may produce similar reactions. The intrusions probably experienced regional metamorphism associated with northwest-trending deformation, as proposed for Ohanapecosh alteration, superimposed upon alteration that occurred during late-stage crystallization.

Quaternary Rocks

Trout Creek Basalt, 01 ivine basalt originated from the Trout Creek Hill volcano and flowed southeastward down the Wind River Valley to the Columbia River. The basalt flowed around both sides of Bunker Hill, disrupting the course of the Wind River east of Bunker Hill. The flow dammed both Panther and Bear Creeks, causing terrace formation along lower Panther Creek. Basalt also damed the Columbia River, resulting in deposition of deltaic sediments (Wise, 1961). 
Wise (1961) believed several tlows erupted from the Trout Creek Hill volcano. No evidence was found in this study of sedimentary interbeds or baked contacts within the basalt, which would have been indicative of multiple flows. A $70 \mathrm{~m}$ thickness of Trout Creek basalt can be observed in the Wind River gorge under the "High Bridge" on the Wind River Highway north of Carson. A continuous outpouring of basalt could form such a great thickness with no interbeds or baked contacts, but it is possible that the Trout Creek basalt may have been a series of intracanyon flows, erupted over a relatively short time, confined to a relatively narrow gorge and not entirely filling the present broad valley. Following a succession of intracanyon flows, the recutting of the gorge beneath the High Bridge could today be exposing several different flows. In future studies, flow units may be separable by vertical variations in vesicularity or trace element chemistry, and thus determine the number of eruptive pulses from Trout Creek Hill volcano during its short period of activity.

The basalt is characterized by megascopic clots of glassy, light green olivine in a dark grey, diktytaxitic groundmass. Subhedral labradorite laths $\left(A n_{63}\right)$ accompany the rounded, iddingsitized olivine. Groundmass constituents are microlite feldspar $\left(A n_{53}\right)$, granular pyroxene and glass. The presence of unaltered glass within the rock as well as relatively youthful lava flow morphology of the unit suggest the basalt is late Pleistocene in age. A K-Ar radiometric age date of 338,000 years was determined for basalt collected from a distal portion of the flow, near the Columbia River (see sample 17 in table 1 and plate I). This is in agreement with a $K-A r$ age date of 340,000 years for basalt collected from Trout Creek Hill (Hammond, 1982, personal communication). 
Quaternary sediments. Poorly lithified to unlithified sedimentary materials of Quaternary age occur throughout the Wind River valley. Glacial deposits are found pasted on the valley walls and high banks of the Hind River, especially along the Wind River Highway south of Stabler. Unstratified till in these deposits includes cobbles and boulders of hornblende diorite, quartz diorite, andesite, and basalt. Recent surficial deposits include glacial drift, alluvium, and landslides of Grande Ronde Basalt, and Stevenson Ridge lavas overlying weathered Ohanapecosh Formation. Crossbedded sands overlie Trout Creek basalt southeast of Carson, near the mouth of the Wind River. According to Wise (1961), a flow of Trout Creek basalt temporarily dammed the Wind and Columbia Rivers, creating a deltaic environment in the area southeast of Carson. Tributaries of the Wind River were also affected by the Trout Creek basalt. Flattened stream gradients in tributaries on the east side of the Wind River valley resulted in deposition of terrace gravels and sands. Summary of Rock Units and Stratigraphy

The oldest geologic unit, the Ohanapecosh Formation of 01 igocene age, may represent distal-type volcanism consisting of volcaniclastic rocks and lesser pyroclastic deposits and lava flows. Intrusion of diorites and concomitant hydrothermal alteration of the Ohanapecosh host rocks occurred during regional metamorphism in the Miocene.

About $16 \mathrm{~m} . \mathrm{y}$. ago, intracanyon andesite and basalt of Stevenson Ridge flowed over deeply weathered Ohanapecosh strata in the western and southern portions of the Wind River valley. The Grande Ronde Basalt erupted shortly afterwards to the east, and flowed over deeply weathered Ohanapecosh Formation. 
The quartz diorite of Wind Mountain intruded the Ohanapecosh and overlying Grande Ronde Basalt. The northernmost diorite intruding Ohanapecosh Formation, at Warren Ridge, is 23 m.y. old, pre-dating Wind Mountain. Other intrusions of slightly varying mineralogy occur along the river valley, and are believed to be Miocene or younger in age.

0livine basalt erupted over a short time interval in the Pleistocene from Trout Creek Hill volcano, partly filling the Wind River valley. Deltaic and terrace sediments were deposited marginal to the lava flow where it dammed the Wind and Columbia Rivers and tributaries to the Wind River.

\section{GEOLOGIC STRUCTURES}

Wise (1961) believes the Wind River area to be in a southwest-dipping homocline, possibly part of a reactivated, pre-Cenozoic structure (Hammond, 1980). Bedding in the Ohanapecosh Formation and Stevenson Ridge lavas is horizontal or dips gently to the west.

Some structural discontinuity exists along the Wind River valley. The valley forms a well-defined lineament trending about $N 45^{\circ} \mathrm{W}$ from the Columbia River near Carson to beyond the study area. The presence of hot springs and intrusive bodies aligned along the lineament (figure 5) indicates the existence of a crustal weakness that has allowed the ascent of magma to near the surface. Such a weakness could be related to the homocline of Wise (1961).

It is not necessary for this "Wind River zone" to be a major fault zone. There is no topographic expression of a fault lying along the west side of the valley, nor geologic evidence of a fault on the east side that might intersect Pilot Knob. However, a fault may lie centrally in 


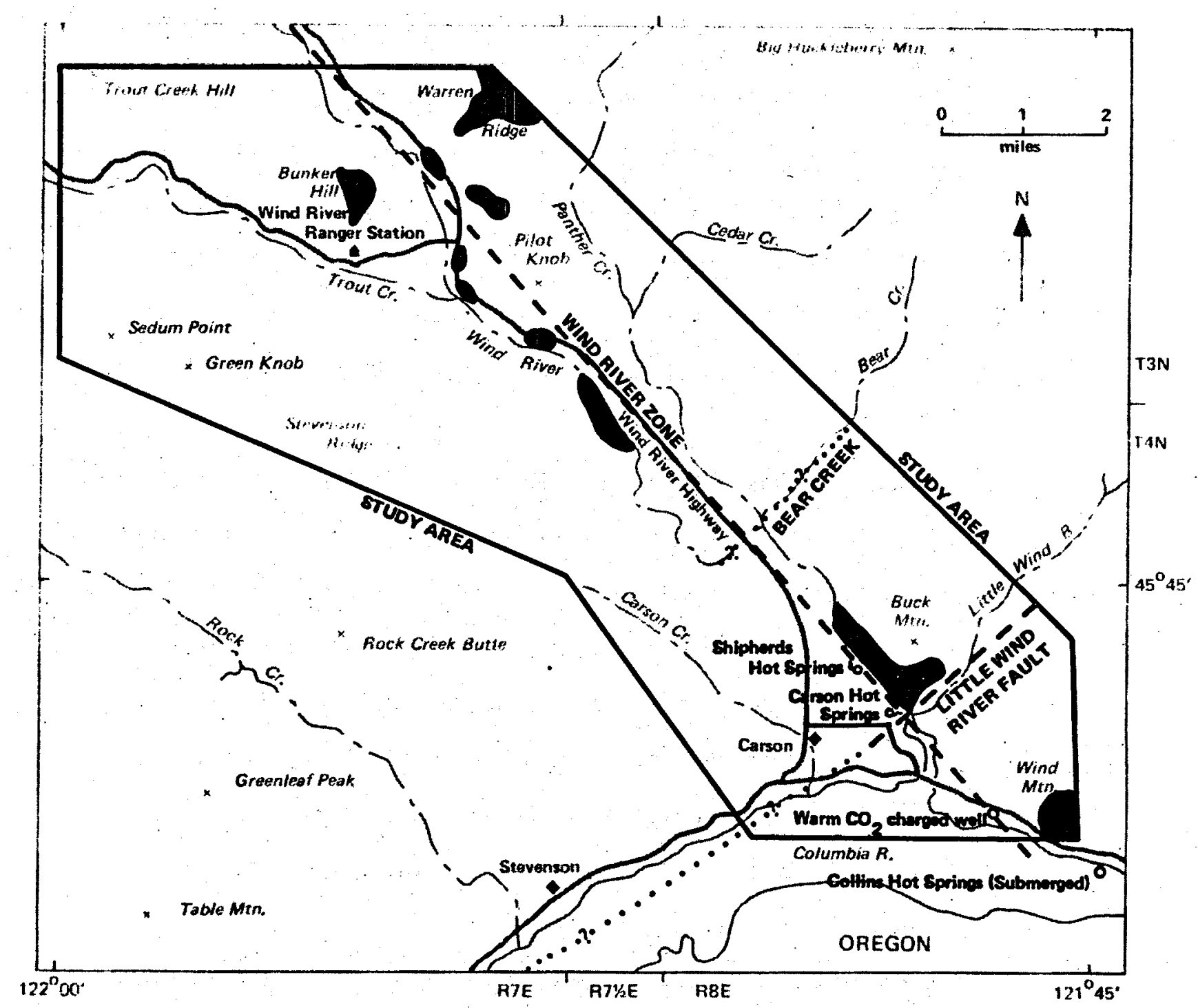

Figure 5. Relationships of intrusive bodies (shaded) and hot springs to structures, Lower Wind River valley. 
the valley and be buried under Trout Creek basalt. A more westerly splinter off the Wind River zone could pass south of Bunker $\mathrm{HIII}$ and through Trout Creek Hill Yolcano, suggesting one mechanism for eruption of the basalt. However, any direct evidence of faulting is lacking.

If the Stevenson Ridge lavas filled a paleovalley, and the contact of the lavas with Ohanapecosh Formation is unconformable, then the true top of the Ohanapecosh on the west side of the study area was probably many hundreds of meters higher in elevation prior to fluvial erosion. Because of such possibilities, offset cannot be determined from elevations of the eroded tops of the formation on either side of the present valley.

Even though it has not been possible to correlate rock types (subunits) across the valley, it is likely that irregularities of topography and local depositional environments resulted in extreme lateral discontinuity of Ohanapecosh subunits. A major northwest-trending fault is not necessary to create geologic features observed in the Wind River area. Because very little geologic evidence of such a fault was observed, the Wind River Valley area is believed to be a zone of crustal weakness related to regional stress systems that allowed intrusive activity and associated hot springs along its length.

The northeast-trending lineament which is formed by the Columbia River west of Carson and continues east along the Little Wind River (figure 5) is another important structure within the study area. This lineament intersects the Wind River zone near the Carson Hot Springs, south of Buck Mountain, and is referred to as the Little Wind River fault. Two northeast-trending, south-dipping fault zones exposed in the walls of the Wind River gorge near the Carson Hot Springs further support the concept of a Little Wind River fault. The intensely fractured zones occur within diorite of the Buck Mountain intrusion, and 
trend N. $44^{\circ}$ E., $60^{\circ}$ S. and N. $48^{\circ}$ E., $85^{\circ}$ S. Clay alteration is common, as well as silica and zeolite fracture coatings.

The northeast-trending fracture zones post-date the Buck Mountain intrusion. The diorite may have been emplaced along the Wind River zone, but was later cut by younger northeast-trending fractures of the little Wind River fault. High vertical cliffs of diorite are present only on the sides of Buck Mountain that correspond to the Little Wind River fault and the Wind River zone. It is not known if diorite was indeed downdropped south of the Little Wind River fault since this area is now covered by landslide debris.

The offset of the northwesterly trend of the Wind River at its junction with Bear Creek may be due to a fault trending along Bear Creek, parallel to the Little Wind River fault. A tuff breccia subunit of the Ohanapecosh is exposed on the northwest side of upper Bear Creek, but not on the southeast side, implying downdrop to the southeast.

\section{GEOCHEMISTRY}

Seventeen samples were analyzed by $x$-ray fluorescence spectrometry for eleven major oxide abundances. These data are reported in tables 3 , 4, and 5. Locations of samples are plotted on plate I.

Variation diagrams were plotted for major oxides versus $\mathrm{SiO}_{2}$ (figure 6). The igneous rocks show a trend over time of decreasing $\mathrm{SiO}_{2}$ and $\mathrm{K}_{2} \mathrm{O}$ and an increase of other major oxides. However, with the exception of Trout Creek basalt, all volcanic rocks are presumed to have originated outside of the study area, thus a genetic association between members of a "Wind River suite" that formed over a period of $30 \mathrm{~m} . \mathrm{y}$. or more is not practical. The Wind River rock record reflects a regional trend toward more mafic compositions with time, as well as multiple source areas. 
TABLE 3.

Chemical analyses of Tertiary lavas and volcaniclastic rocks.

\begin{tabular}{|c|c|c|c|c|c|c|c|c|c|c|c|}
\hline \multicolumn{12}{|c|}{ Sample Number } \\
\hline & & & & & & $I$ & 2 & 7 & $\Pi$ & 13 & 16 \\
\hline $\mathrm{SiO}_{2}$. & - & - & $\cdot$ & - . & & 52.39 & 67.27 & 63.15 & 64.30 & 54.32 & 54.58 \\
\hline $\mathrm{TiO}_{2}$. & - & - & $\cdot$ & - • & • & 1.85 & 0.76 & 1.05 & 0.72 & 1.50 & 1.70 \\
\hline $\mathrm{Al}_{20}$. & • & - & - & - • & • & 16.87 & 14.09 & 15.62 & 14.87 & 17.72 & 15.97 \\
\hline $\mathrm{Fe}_{2} \mathrm{O}_{3}$ & • & • & $\cdot$ & . . & 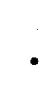 & 5.35 & 3.23 & 3.59 & 3.02 & 4.33 & 5.03 \\
\hline $\mathrm{FeO}$. & • & - & $\cdot$ & - $•$ & • & 6.12 & 3.70 & 4.11 & 3.46 & 4.96 & 5.76 \\
\hline MnO. . & • & - & $\cdot$ & - $\cdot$ & · & 0.19 & 0.16 & 0.18 & 0.18 & 0.16 & 0.17 \\
\hline MgO. . & • & - & $\cdot$ & - $•$ & . & 4.01 & 1.04 & 1.80 & 1.17 & 3.51 & 3.61 \\
\hline $\mathrm{CaO}$. & • & - & $\cdot$ & - $•$ & . & 8.20 & 2.87 & 5.80 & 6.55 & 8.23 & 7.55 \\
\hline $\mathrm{Na}_{20}$. & - & - & $\cdot$ & • & 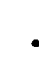 & 3.74 & 4.36 & 3.10 & 2.94 & 4.01 & 4.15 \\
\hline $\mathrm{K}_{20}$. & • & - & • & - • & 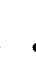 & 0.98 & 2.28 & 1.37 & 1.76 & 0.98 & 1.17 \\
\hline $\begin{array}{l}\mathrm{P}_{20} \mathrm{O}_{5} . \\
\text { TOTAL. }\end{array}$ & $\dot{.}$ & $\dot{\cdot}$ & $\dot{.}$ & $\dot{\circ}$ & & $\begin{array}{r}0.29 \\
99.99 \\
\end{array}$ & $\begin{array}{r}0.22 \\
99.98 \\
\end{array}$ & $\begin{array}{r}0.24 \\
100.01 \\
\end{array}$ & $\begin{array}{r}1.03 \\
100.00\end{array}$ & $\begin{array}{r}0.29 \\
100.01 \\
\end{array}$ & $\begin{array}{r}0.30 \\
99.99 \\
\end{array}$ \\
\hline
\end{tabular}

Locations of Samples:

1. Tholeitic basalt, east of Sedum Point; Stevenson Ridge lava(?), 4N/7E/31B.

2. Pyroxene dacite, south of Ranger Station; Ohanapecosh Formation, $4 \mathrm{~N} / 7 \mathrm{E} / 27 \mathrm{C}$.

7. Andesitic volcaniclastic sediment, east of Pilot Knob; Ohanapecosh Formation, $4 N / 71 / 2 E / 24 C$.

11. Andesitic tuff breccia, Bear Creek; Ohanapecosh Formation, $3 \mathrm{~N} / 8 \mathrm{E} / 6 \mathrm{C}$.

13. Pyroxene basaltic-andesite, southeast Stevenson Ridge; Stevenson Ridge Lava, $3 N / 8 E / 180$.

16. Pyroxene basaltic-andesite, quarry southwest of Carson; Stevenson Ridge Lava, 3N/8E/29D. 
TABLE 4.

Chemical Analyses of Intrusive Rocks

\begin{tabular}{|c|c|c|c|c|c|c|c|c|c|c|c|c|}
\hline \multicolumn{13}{|c|}{ Sample Number } \\
\hline & & & & 3 & 4 & 5 & 6 & 8 & 9 & 10 & 14 & 15 \\
\hline $\mathrm{STO}_{2}$ & - & $\therefore$ & $\therefore$ & 53.60 & 56.56 & 56.91 & 56.69 & 61.77 & 55.10 & 57.64 & 59.41 & 59.07 \\
\hline $\mathrm{THO}_{2}$ & 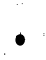 & • • & $\therefore$ & 1.35 & 1.78 & 1.92 & 1.84 & 1.44 & 1.81 & 1.88 & 1.07 & 0.92 \\
\hline $\mathrm{Al}_{203}$ & . & 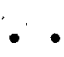 & - . & 19.20 & 16.43 & 15.45 & 15.86 & 14.76 & 15.93 & 16.40 & 16.61 & 17.47 \\
\hline $\begin{array}{l}\mathrm{Fe}_{203} \\
\mathrm{FeO} \\
\mathrm{MnO} \\
\mathrm{MgO} \\
\mathrm{CaO} \text {. }\end{array}$ & $\begin{array}{l}\because \\
\vdots \\
\bullet\end{array}$ & $\begin{array}{l}\cdot \\
\bullet \\
\bullet \\
\bullet \\
\bullet\end{array}$ & $\begin{array}{l}\cdot \because \\
0 \\
0 \\
\bullet\end{array}$ & $\begin{array}{l}4.34 \\
4.98 \\
0.15 \\
3.01 \\
8.01\end{array}$ & $\begin{array}{l}5.10 \\
5.84 \\
0.19 \\
2.61 \\
5.42\end{array}$ & $\begin{array}{l}4.85 \\
5.56 \\
0.20 \\
2.81 \\
6.20\end{array}$ & $\begin{array}{l}4.78 \\
5.48 \\
0.19 \\
3.03 \\
5.91\end{array}$ & $\begin{array}{l}4.42 \\
5.06 \\
0.18 \\
1.48 \\
5.57\end{array}$ & $\begin{array}{l}5.49 \\
6.28 \\
0.22 \\
3.20 \\
6.42\end{array}$ & $\begin{array}{l}4.26 \\
4.89 \\
0.17 \\
2.81 \\
5.87\end{array}$ & $\begin{array}{l}3.47 \\
3.98 \\
0.12 \\
3.65 \\
6.62\end{array}$ & $\begin{array}{l}3.19 \\
3.66 \\
0.11 \\
3.80 \\
6.45\end{array}$ \\
\hline $\mathrm{Na}_{20}$. & $\therefore$ & & - & 4.33 & 4.77 & 4.01 & 4.15 & 3.50 & 4.24 & 4.29 & 3.73 & 4.02 \\
\hline $\mathrm{K}_{20}$ & & • & • & 0.78 & 1.02 & 1.61 & 1.64 & 1.37 & 0.99 & 1.49 & 1.10 & 1.14 \\
\hline $\begin{array}{l}\mathrm{P}_{20_{5}} . \\
\text { TOTAL }\end{array}$ & - & . & . & $\begin{array}{r}0.24 \\
99.99\end{array}$ & $\begin{array}{r}0.29 \\
100.01\end{array}$ & $\begin{array}{r}0.48 \\
100.00\end{array}$ & $\frac{0.44}{100.01}$ & $\begin{array}{r}0.46 \\
100.01\end{array}$ & $\frac{0.32}{100.00}$ & $\frac{0.31}{100.01}$ & $\frac{0.22}{99.98}$ & $\frac{0.16}{99.99}$ \\
\hline
\end{tabular}

Locations of Samples:

3 - Gabbro, Bunker Hill; 4N/7E/220; BH-1, Table II.

4 - Diorite/andesite, south crest of Warren Ridge; $4 N / 7 E / 13 B$.

5 - Diorite, south base of Warren Ridge on Wind River Highway; 4N/7E/23B; WAR-4; Table 2.

6 - Diorite, north Pllot Knob; 4N/7E/24B.

8 - Diorite, northwest Pllot Knob; 4N/7E/26A; WR-1, Table 2.

9 - Diorite, west Pilot Knob; $4 N / 7 E / 260$.

10 - Diorite, southwest Pllot Knob; 4N/7E/36A; HR-7, Table 2.

14 - Diorite, Buck Mountain intrusion, north of fish ladder; $3 N / 8 E / 21 B$.

15 - Diorite, Buck Mountain intrusion, opposite Carson Hot Springs; 3N/8E/21D; WR-13, Table 2.

Analyst: P. R. Hooper, Washington State University, Pullman, Washington 
TABLE 5.

Chemical Analyses of Trout Creek Basalt

\begin{tabular}{|c|c|c|c|c|c|c|c|c|c|}
\hline & & & & & & & & $\frac{\text { Sample }}{12}$ & $\frac{\text { Number }}{17}$ \\
\hline $\mathrm{SiO}_{2}$. & - & - & - & - & - . & . & . & 51.09 & 50.21 \\
\hline $\mathrm{TiO}_{2}$. & - & . & • & & • • & • & - & 1.14 & 1.11 \\
\hline $\mathrm{Al}_{2 \mathrm{O}_{3}}$ & - & • & • & • & . - & - & . & 17.45 & 17.91 \\
\hline $\mathrm{Fe}_{2} \mathrm{O}_{3}$ & • & • & • & • & . . & . & . & 4.74 & 4.90 \\
\hline $\mathrm{FeO}$. & - & • & - & • & - . & • & . & 5.43 & 5.61 \\
\hline MnO . & - & - & . & • & - . & • & . & 0.17 & 0.17 \\
\hline $\mathrm{MgO}$. & $\bullet$ & • & • & • & - . & • & - & 7.19 & 7.07 \\
\hline $\mathrm{CaO}$. & & & • & • & - & . & . & 8.85 & 8.77 \\
\hline $\mathrm{Na}_{20}$ & & & - & • & - • & • & . & 3.42 & 3.73 \\
\hline$K_{20}$. & & & - & • & - . & • & . & 0.35 & 0.32 \\
\hline $\begin{array}{l}\mathrm{P}_{20} \mathrm{O}_{5} \\
\text { TOTAL }\end{array}$ & $\therefore$ & $\div$ & $\dot{.}$ & 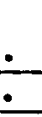 & . & $\dot{.}$ & & $\begin{array}{r}0.17 \\
100.00\end{array}$ & $\begin{array}{r}0.19 \\
99.99 \\
\end{array}$ \\
\hline
\end{tabular}

Locations of Samples:

$$
\begin{aligned}
& 12 \text { - } 01 \text { ivine basalt, north of Bear Creek - } \\
& \text { Panther Creek junction; 3N/8E/6D. } \\
& 17 \text { - } 01 \text { ivine basalt, south of Carson near } \\
& \text { Columbia River; } 3 \mathrm{~N} / 8 \mathrm{E} / 28 \mathrm{D} \text {. }
\end{aligned}
$$

Analyst: P. R. Hooper, Washington State University, Pullman, Washington 

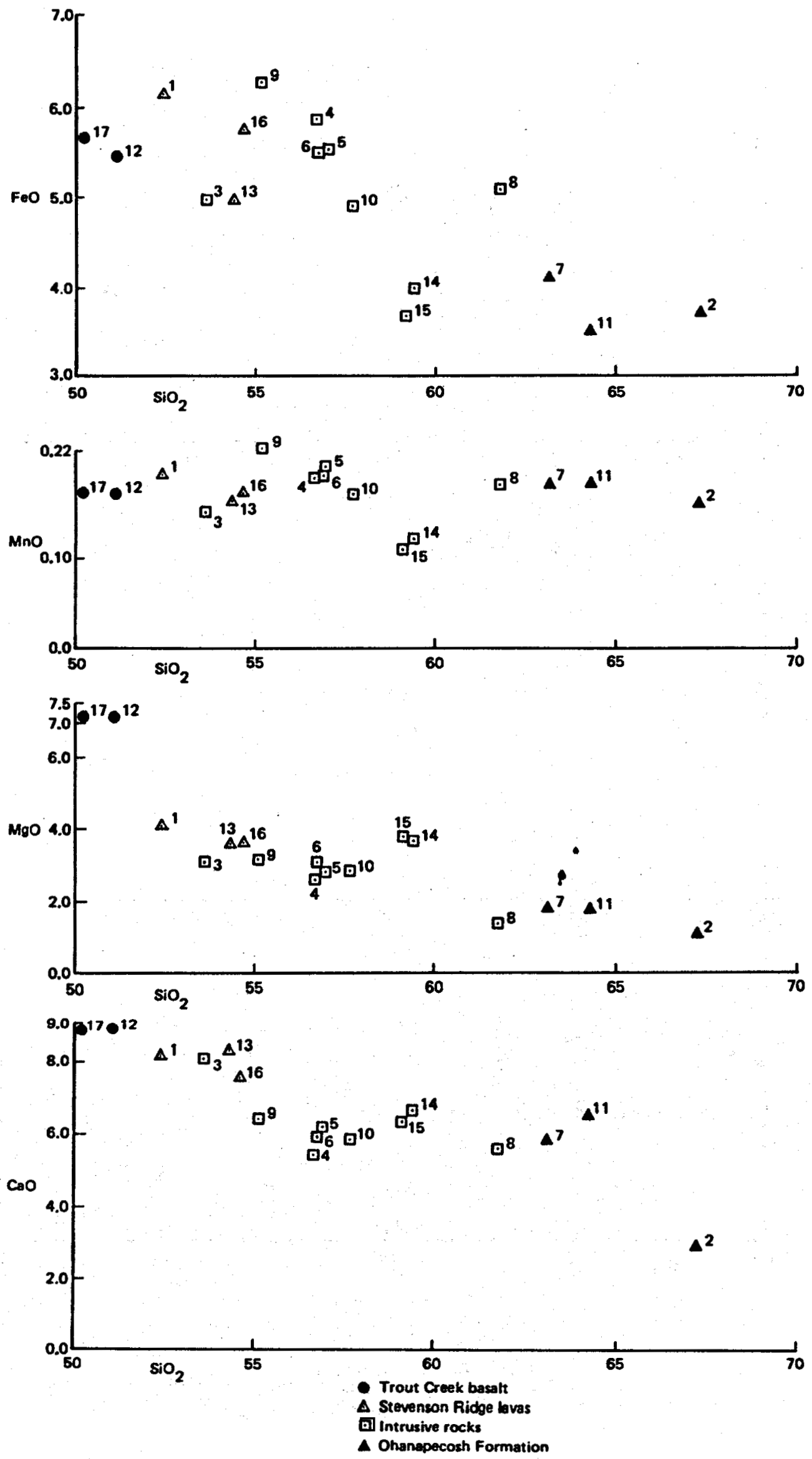

Figure 6. Variation diagrams for major oxides versus silica in Lower Wind River rocks. Oxides are reported in weight percent. The figure is continued on the next 2 pages. 

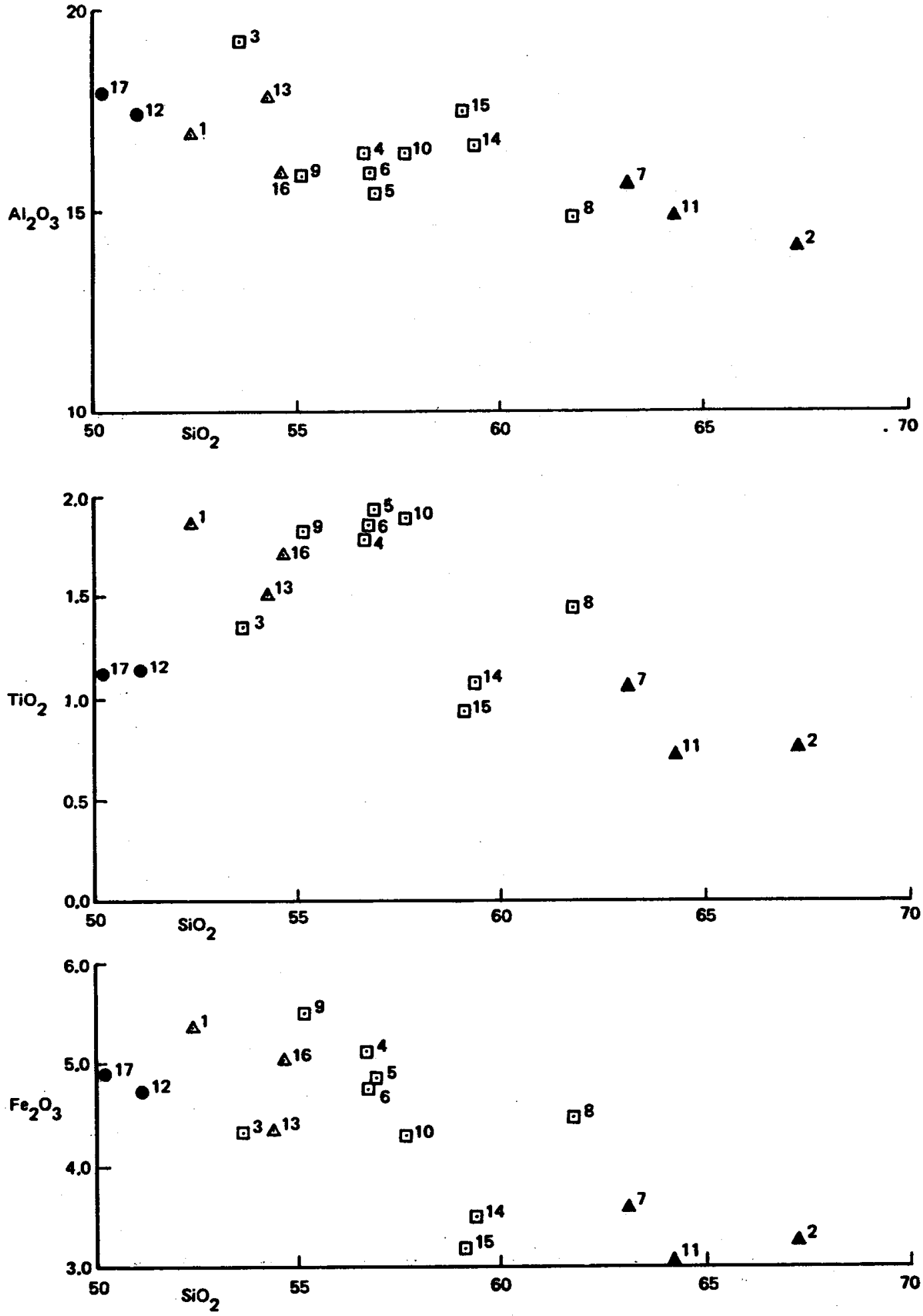

- Trout Creek besalt

A Stevenson Ridge lavs

b intrusive rocks

- Ohanapecosh Formation 

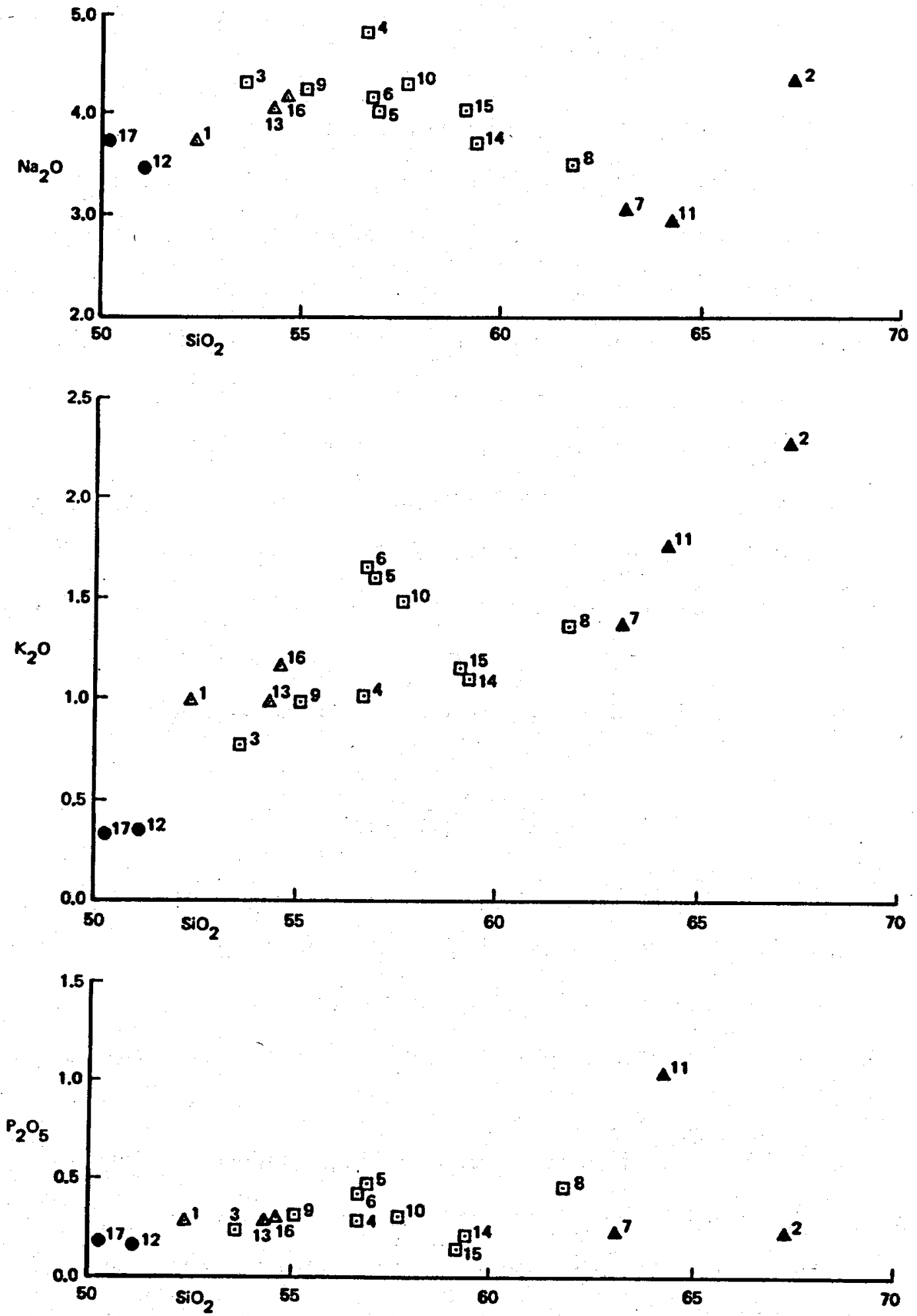

Trout Crook botalt

A Stevemeon Ridge bus

a intrutive rocks

A Ohanapacosh Formation 
Therefore, the chemical evolution of a single Wind River magma cannot be speculated upon.

Lacking more than one diorite age date, it is difficult to determine a sequence of emplacement for the intrusive bodies. The intrusive groups described in table 2 are roughly grouped by chemical composition in figure 6 .

There is considerable range in compositions between the intrusive groups, from 54 to 62 percent $\mathrm{SiO}_{2}$. The quartz diorite of Wind Mountain, analyzed by Wise (1961), extends this range to 66 percent $\mathrm{SiO}_{2}$. At least one of the Pilot knob intrusions is $23 \mathrm{~m} . \mathrm{y}$. old, but the Wind Mountain intrusion post-dates Grande Ronde Basalt, i.e. is younger than 14 m.y. old. The remaining intrusions are similar to the Pilot knob body, but it cannot be assumed they are of similar age merely on the basis of petrographic and chemical compositions. Further age dating may better define the relationship between diorite intrusions in the Wind River valley.

\section{SUBSURFACE GEOLOGY}

Two shallow temperature gradient heat flow holes were drilled by the Washington Division of Geology and Earth Resources in the Wind River area. Locations of the two $152 \mathrm{~m}$ holes are: DNR-7 (Trout Creek drill hole)- 4N/7E/28AA, and DNR-8 (Carson drill hole)- 3N/8E/21BDD (see plate I).

As illustrated in the lithologic logs (figure 7), the Trout Creek drill hole penetrated about $9 \mathrm{~m}$ of olivine basalt from Trout Creek $\mathrm{Hill}$ volcano. This was underlain by $15 \mathrm{~m}$ of alluvium and at least $128 \mathrm{~m}$ of Ohanapecosh Formation. The latter consists primarily of altered fine grained tuffs or tuffaceous sediments, except for a $9 \mathrm{~m}$ thick aphyric basalt. The alluvium interbed proved incompetent during drilling. 


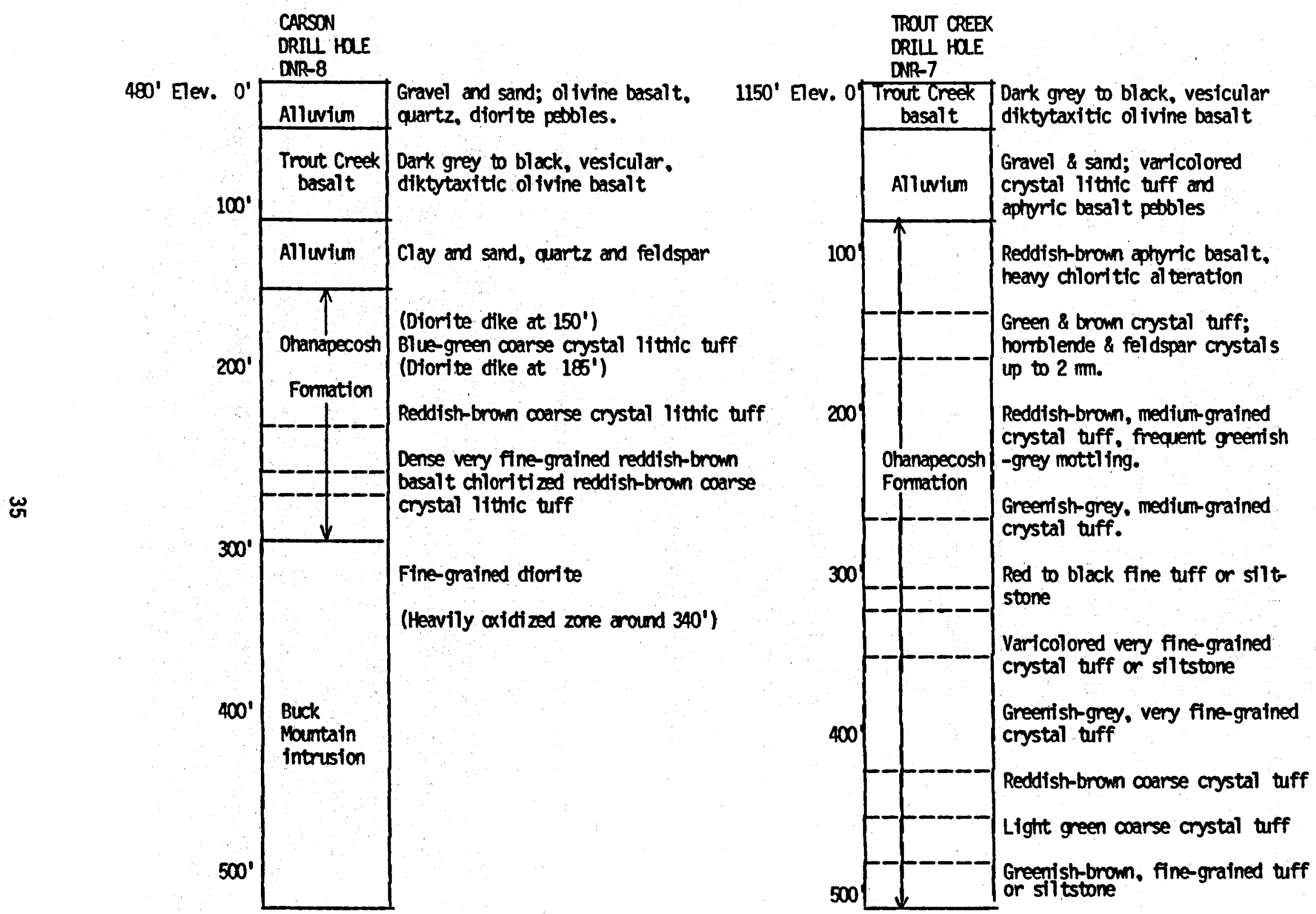

Figure 7. Lithologic logs of drill toles, lower Wind River valley. 
Due to its position between the Trout Creek basalt and clayey tuff and lava of the Ohanapecos', the porous material nay function as an aquifer.

The Carson drill hole encountered a considerably greater thickness of Trout Creek basalt (figure 7). The basalt is underlain by $9 \mathrm{~m}(30 \mathrm{ft})$ of alluvium and about $40 \mathrm{~m}$ (130 ft) of Ohanapecosh tuff and aphyric lava. The lower $70 \mathrm{~m}(230 \mathrm{ft})$ of the hole consists of diorite of the Buck Mountain intrusion. Two thin dikes or sills of diorite occur in the overlying Ohanapecosh Formation.

Both drill holes have revealed relatively shallow interbedded alluvium capped by impermeable Trout Creek basalt and underlain by clay-rich units of the Ohanapecosh Formation; thus, the alluvium may serve as a groundwater aquifer. Fracturing of the Ohanapecosh Formation during intrusion of the diorite in DNR-8 may further provide routes for heated meteoric water ascending from the Buck Mountain intrusion.

\section{EVALUATION OF GEOTHERMAL RESOURCE POTENTIAL}

\section{Setting}

The Wind River area, in the southwestern Cascade Range of Washington, is underlain chiefly by volcaniclastic strata several $\mathrm{km}$ thick and about $500 \mathrm{~m}$ of andesitic lava flows of 01 igocene to middle Miocene age. The lower volcaniclastic rocks form part of the Ohanapecosh Formation and the unconformably overlying lava flows are named the Stevenson Ridge lavas. The Stevens Ridge Formation and lava flows of Three Corner Rock, recognized by Hammond (1980), were not recognized in the area, al though Stevenson Ridge lavas are believed to correlate with Three Corner Rock lavas. 
By middle Miocene time the strata had been warped to form a southwestdipping homocline and were intruded by a number of small stocks and thick sills of gabbro, diorite, and quartz diorite, along a northwest-trending zone paralleling the strike of the homocline. Low-grade zeolite facies metamorphism producing zeolites and chlorite pervasively affected the rocks at this time. This zone is presently followed by the course of the lower Wind River. Although a fault is not delineated along the valley, stratigraphic differences between the valley sides and the persistent topographic. expression of the valley strongly suggest that a structural zone underlies the valley floor.

The northeast-trending Little Wind River fault formed after the intrusions were emplaced. Hot springs localized near the junction of the fault with the Wind River zone (figure 5) suggest there may be a latent heat source at depth, reached by groundwater circulation through the Little Wind River fault. The two hot springs of figure 5 , however, are located along the Wind River zone, thus the Little Wind River fault probably served to reactivate or reopen fractures along the pre-existing Wind River zone.

Geochemical studies of the spring water have determined it is not magmatic in origin (Campbell and others, 1970, Korosec and others, 1983). Although the Quaternary Trout Creek basalt may locally offer latent thermal energy, the hot springs are located a great distance from the basaltic vent, and thus, the Quaternary volcano is not believed responsible for hot spring activity. Evidence of active or fossil hot springs activity. elsewhere in the lower Wind River valley is lacking. It is believed, therefore, that the intersection of the two structural zones shown in figure 5 near an intrusive mass is directly responsible for the hot spring 
development. If heat is indeed supplied by a cooling intrusion, the present-day activity of the hot springs near the Buck Mountain intrusion suggests this particular diorite body may be young, perhaps closer in age to nearby Wind Mountain (post-Columbia River Basalt) than to diorite of Pilot knob (23 m.y.), located over $13 \mathrm{~km}$ to the northwest, but even this would be too old to supply significant heat.

Nature of the Thermal Water and Heat Source

Physical and chemical characteristics of the Carson and Shipherds Hot Springs are listed in table 6. Accelerated dissolution of silicate minerals by the thermal waters has resulted in high $\mathrm{pH}$ and dissolved $\mathrm{SiO}_{2}$ values. The high total dissolved solids (TDS) and related high conductivity of the Carson Hot Springs water suggest either, 1) that much of it is connate or formational water from buried sedimentary rocks, which tend to contain elevated $\mathrm{Na}$ and $\mathrm{Cl}$ ion abundances, or 2) extensive weathering and prolonged contact by the fluid with sedimentary rocks occurred, concentrating $\mathrm{Cl}$ ions.

The lower values of conductivity, TDS, $\mathrm{Cl}$ and $\mathrm{Na}$ ions in Shipherds Hot Springs suggest there may be more mixing with dilute surface waters, especially Wind River water, than occurs at Carson Hot Springs. The hot springs are less than $800 \mathrm{~m}$ north of Carson Hot Springs (see figure 5) and occur in Buck Mountain diorite. It is not known if there is a fault intersection controlling location of these springs. The water may be migrating along fractures away from the Wind River-Little Wind River fault intersection, surfacing upstream as slightly cooler, more dilute water. Fractures were observed within units of the Ohanapecosh Formation in drill hole DNR-8, near the Shipherds Hot Springs. 
TABLE 6.

Characteristics of two Wind River hot springs

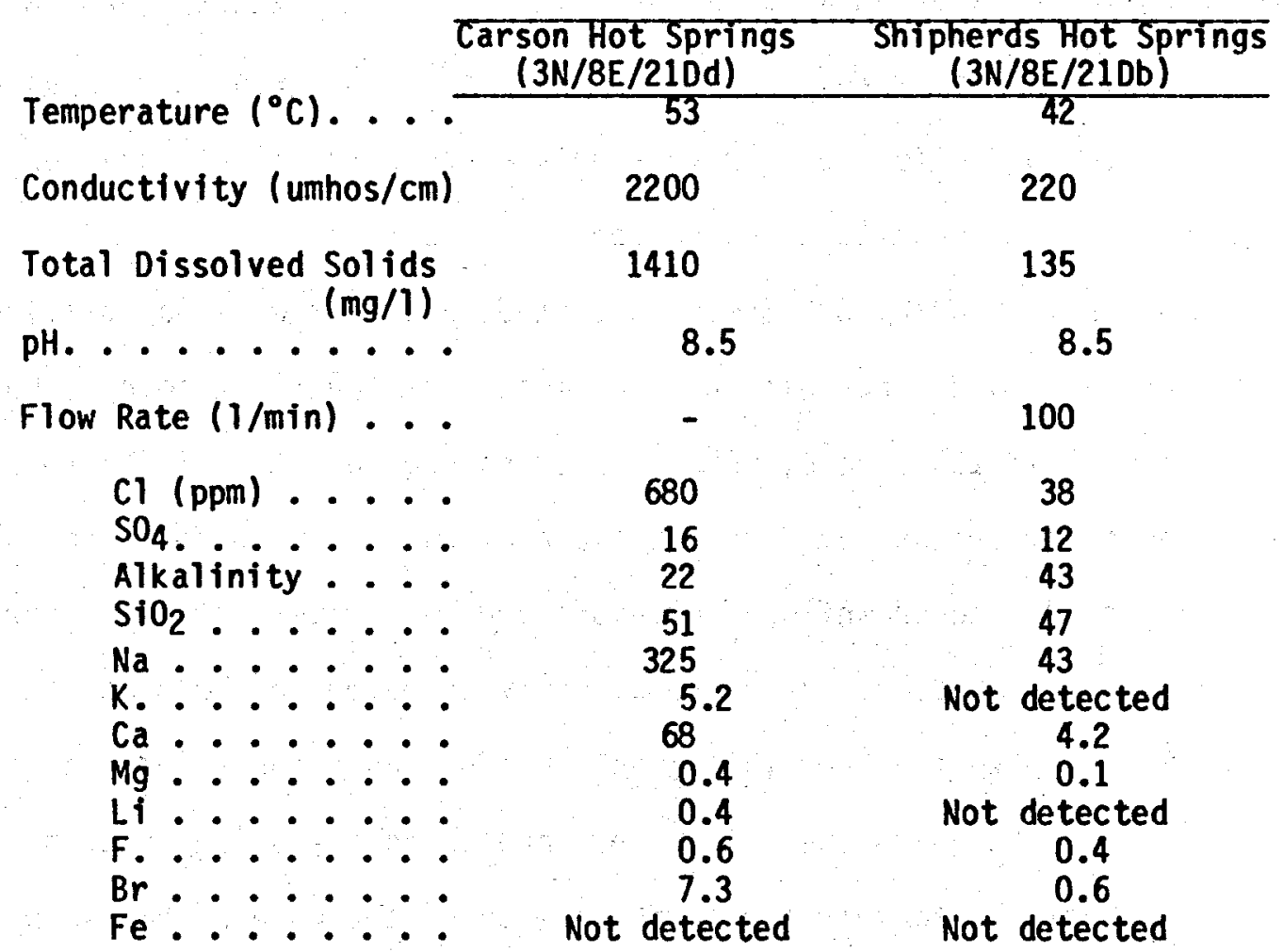

Geothermometers:

\begin{tabular}{lrr}
$\mathrm{Na} / \mathrm{Li}\left({ }^{\circ} \mathrm{C}\right)$ & 88 & - \\
$\mathrm{Na}-\mathrm{K}-\mathrm{Ca}$. & 100 & - \\
$\mathrm{SiO}_{2}$ (quartz). & 103 & 99 \\
$\mathrm{SiO}_{2}$ (chalcedony). & 73 & 69 \\
\hline
\end{tabular}

Sources: Temperature, TDS, Flow Rate - Korosec and others (1981) A11 other data - M. Korosec, Washington Dept. of Natural Resources (personal communication). 
Geothermometers suggest that both hot springs originate from a source having an average temperature of around $90^{\circ} \mathrm{C}\left(195^{\circ} \mathrm{F}\right)$. Depth to this subsurface reservoir is not indicated by geochemical data.

The temperature gradient in the lower portion of the Carson drill hole (DNR-8) was measured to be extremely high, $365^{\circ} \mathrm{C} / \mathrm{km}$ (see figure 8). With a bottom hole temperature of only $28^{\circ} \mathrm{C}$ at $114 \mathrm{~m}$, and springs in the vicinity with temperatures as high as $45^{\circ} \mathrm{C}$, the high gradient was assumed to be due to conduction between the surface and a relatively shallow warm aquifer, at least $45^{\circ} \mathrm{C}$, which feeds the springs.

About a year after DNR-8 was completed, a deeper well was drilled by the private land owner within a few meters of the first hole. The Hegewald well is $190 \mathrm{~m}$ deep, with a lower-hole gradient of $153^{\circ} \mathrm{C} / \mathrm{km}$ and a bottom hole temperature of $36^{\circ} \mathrm{C}$. Because of water flow within the hole, including cold water downflow from above and warm water downflow near the bottom, the gradient cannot be directly compared to the gradient of DNR-8. Despite the fact that a hot aquifer was encountered, the low temperature relative to the hot springs and the observation that the gradient continues to increase at the bottom of the hole suggests that the main hot water aquifer had yet to be reached. Using a gradient of $150^{\circ} \mathrm{C} / \mathrm{km}$, the hot spring temperature of $45^{\circ} \mathrm{C}$ would be reached at about $250 \mathrm{~m}$, and the predicted reservoir temperature of $90^{\circ} \mathrm{C}$ would be reached at 550 meters.

A gradient of $84.3 \pm 1.08^{\circ} \mathrm{C} / \mathrm{km}$ exists in the Trout Creek drill hole. This gradient may reflect a very high regional gradient, or may be due to latent Quaternary volcanic heat associated with the Trout Creek Hill volcano. No intrusions or faults are known in this area. 


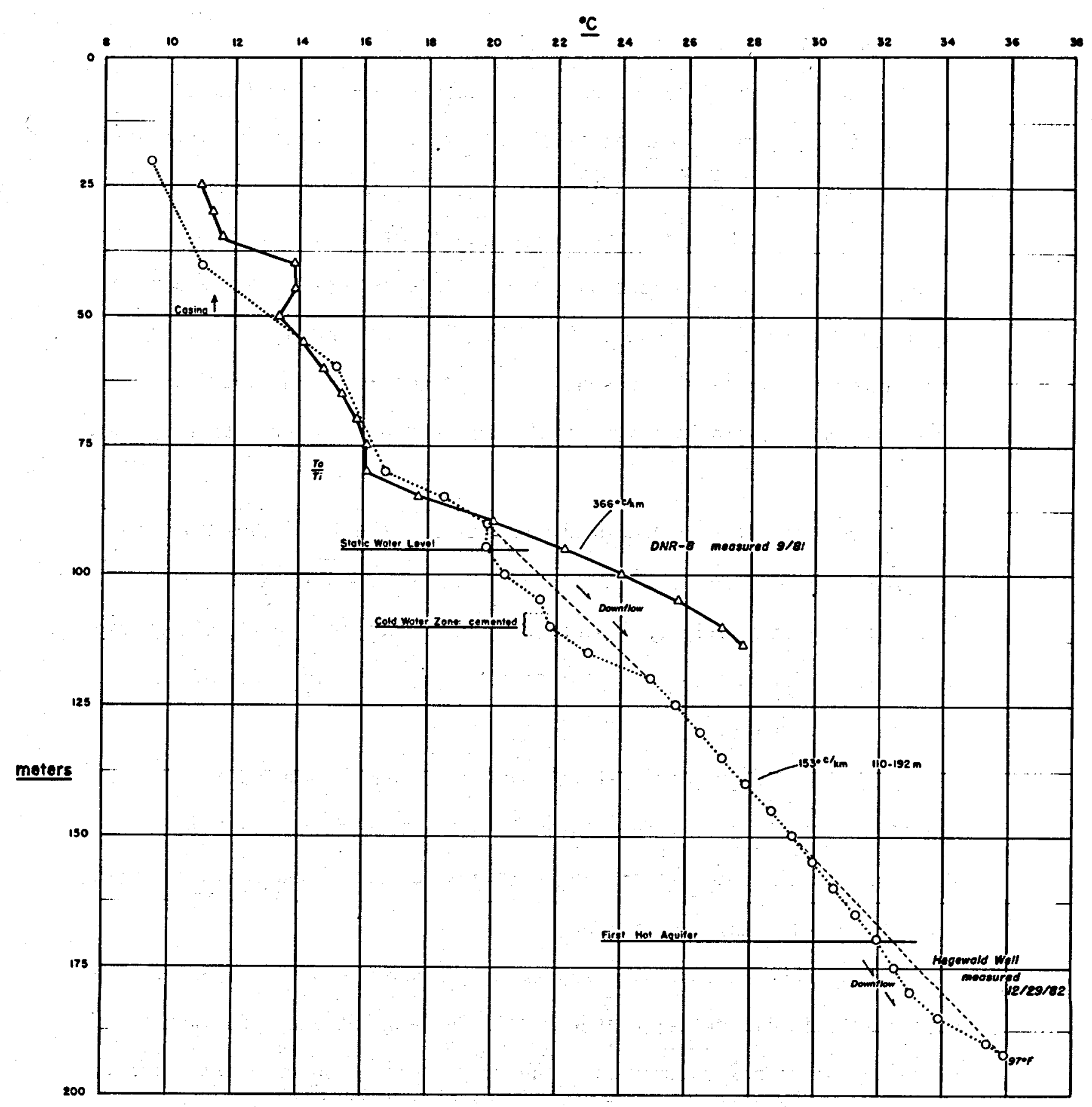

Figure 8. Temperature vs. Depth diagram for DNR-8 and Hegewald Well. 


\section{Geothermal Resource}

Volcanic activity has occurred in recent times, as indicated by the Pleistocene Trout Creek basalt. Latent volcanic heat significantly raises geothermal gradients. The evidence of this report shows that only one eruptive phase is associated with Trout Creek Hill volcano. Certainly, repeated eruptions over a long time interval provide a more encouraging geothermal prospect, and further work on this aspect may prove it to be the case. Present field, petrographic and chemical data support only a single lava type that erupted rapidly over a short period of time.

The moderate temperature gradient found in the Trout Creek drill hole should be further explored. Deeper holes would indicate if the gradient could be reliably projected to deeper depths, and would provide more information on the nature of possible aquifers in units of the Ohanapecosh Formation.

Water well logs show that the Quaternary basalt may be as much as $90 \mathrm{~m}$ thick in places. Temperatures in wells penetrating this valley filling basalt may be significantly lowered by cool ground water flowing through or below the basalt flows.

Slowly cooling intrusive bodies may be sources of heat, but they must be of significant size and/or relatively young age. Further study of these intrusions could define their age relationships, particularly if the bodies were progressively emplaced from south to north or north to south as the Wind River zone developed. Positions of the youngest, hottest, and possibly still concealed intrusions would then be located at the younger end of the zone. The relatively young Wind Mountain intrusion and the Buck Mountain intrusion with its related hot springs 
lie at the south end of the Wind River zone in Washington. Shellrock Mountain is a quartz diorite plug that crops out directly across the Columbia River from Wind Mountain and also intruded Columbia River Basalt. The Wind River zone, may, therefore, have developed from north to south, and may extend southward into Oregon.

The occurrence of the thermal waters near Carson is attributed to the intersection of two structural zones over an intrusive body that yielded heat to circulating groundwater.

The $90-100^{\circ} \mathrm{C}$. estimated reservoir temperature at the Carson and Shipherds Hot Springs is not within the range of conventional geothermal power production. Many possible applications exist, however, including space heating of homes, schools, offices or greenhouses, as well as lowertemperature uses such as food processing, fish farming, soil warming, and various co-generation processes. Numerous potential users of this resource exist at the south end of the Wind River valley and along the Columbia River Gorge.

\section{SUMMARY AND CONCLUSIONS}

The lower Wind River drainage consists primarily of the Ohanapecosh Formation, an 01 igocene unit that is recognized across the entire southern Washington Cascade Range. The formation is at least $300 \mathrm{~m}$ thick in the Wind River valley area. It cons ists largely of volcaniclastic sediments, with minor massive pyroclastic flows, volcanic breccias and lava flows. Low grade zeolite facies metamorphism during the Miocene led to formation of hydrothermal minerals in Ohanapecosh strata. Metamorphism probably occurred at less than $180^{\circ} \mathrm{C}$. 
Stevenson Ridge lavas flowed over deeply weathered volcaniclastics of the Ohanapecosh Formation. The montmorillonite surface facilitated later sliding of the lavas. Stevenson Ridge lavas consist of pyroxene andesite and minor basalt flows up to $30 \mathrm{~m}$ thick. The lavas, K-Ar age dated at 15.7 m.y., may be intracanyon flows that filled an ancient course of the Wind River.

Nearly aphyric Yakima Basalt flows, slightly younger than Stevenson Ridge lavas, occur north and east of Wind Mountain. Yakima Basalt overlies montmorillonite of the upper Ohanapecosh, and is disrupted by large active and inactive slides near Wind Mountain.

Wind Mountain is a quartz diorite pluton that intruded the Ohanapecosh and Yakima Basalt in the late Miocene or Pliocene. Several smaller dioritic intrusions, one dated at $23 \mathrm{~m} . \mathrm{y}$. old, occur within the Ohanapecosh to the north along the Wind River. Hydrothermal alteration of the diorites may have been induced by late-stage crystallization as well as by regional metamorphism in the Miocene. Bunker $\mathrm{Hill}$ is the single mafic intrusion in the valley.

The Trout Creek basalt is a $70 \mathrm{~m}$ thick series of intracanyon olivine basalt flows. Eruptions occurred over a short time interval about 338,000 years ago. The lavas disrupted streams along the Wind River valley and temporarily dammed the Columbia River. Deltaic and terrace sediments were deposited marginal to the lavas.

A gently southwest-dipping structure affects the lower Wind River valley. Normal to this is the northwest-trending Wind River zone, a topographic lineament including aligned intrusions and hot springs but no direct evidence of faulting. The Wind River zone is a crustal weakness, possibly related to northwest-trending Miocene folds. The northeast- 
trending, south-dipping Little Wind River fault intersects the Wind River zone and cuts the Buck Mountain intrusion. A similarly-oriented fault may coincide with Bear Creek.

Minor chemical trends in intrusive rocks were detected, with $\mathrm{SiO}_{2}$ generally increasing from north to south along the Wind River valley. Further age dates and geochemical analyses are required to verify if this trend represents magmatic differentiation and emplacement of intrusions from north to south over time.

A potential geothermal resource exists near Buck Mountain at the Carson Hot Springs. Exploratory drilling near Buck Mountain shows that the Ohanapecosh Formation, beneath the valley filling Quaternary basalt from Trout Creek $\mathrm{Hill}$, is cut by thin dikes or sills and is underlain by a large mass of diorite. The Little Wind River fault reactivated fractures of the Wind River zone that allow groundwater circulation within the intrusion at depth. Heat at depth, from elevated heat flow, possibly associated with intrusive activity, produces hot spring temperatures of at least $53^{\circ} \mathrm{C}$ and very high temperature gradients locally above the hydrothermal system.

The geologic setting of the Carson Hot Springs suggests fractures cutting the Wind River zone and youthful intrusive bodies may be prerequisite for a geothermal resource in this region. Similar geologic environments may exist at Wind Mountain, Shellrock Mountain, and for the intrusives forming the hills at the head of the Collins Point and Home Valley landslides. Possible temporal development of the Wind River zone from north to south suggests the greatest geothermal potential may lie at the southern end of the zone. The extension of this zone to the south of Shell rock Mountain should be investigated for possible moderate temperature geothermal resources in Oregon. 


\section{ACKNOWLEDGMENTS}

This study was supported by U.S. Department of Energy contract No. DE-ACO7-79ET27014, administered by the Washington Department of Natural Resources, Division of Geology and Earth Resources, for assessment of geothermal resources in Washington. Geologic mapping was carried out by Dulcy Berri under a subcontract from the Division. Contract advisor was Paul Hammond of Portland State University, who provided guidance during field work and critical reviews of the preliminary findings. Field assistants were John Petros, Wayne Adams, and Greg McInnis. Two K-Ar age dates were provided by Stanley Evans, University of Utah Research Institute, operating under a U.S. Department of Energy grant. Discussions with J. Eric Schuster of the Division of Geology and Earth Resources and his contributions to the editing of the final report are gratefully acknowledged. 


\section{REFERENCES}

Allen, J.E., 1932, Contributions to the structure, stratigraphy, and petrography of the lower Columbia River Gorge: University of Oregon, M.S. thesis, $96 \mathrm{p}$.

Allen, J.E., and Sargent, S.C., in press, Cataclysms on the Columbia: A layman's guide to the features produced by the catastrophic Bretz floods in the Pacific Northwest: Timber Press, Beaverton, OR.

Campbell, K.V., Miers, J.H., Nichols, B.M., 01iphant, J., Pytlak, S., Race, R.W., Shaw, G.H., and Gresens, R.L., 1970, A survey of thermal springs in Washington State: Northwest Science, v. 44, p. 1-11.

Chaney, R.W., 1918, The ecological significance of the Eagle Creek flora of the Columbia River Gorge: Journal of Geology, v. 26, no. 7, p. 577-592.

Fiske, R.S., 1963, Subaqueous pyroclastic flows in the Ohanapecosh Formation, Washington: Geological Society of America Bulletin v. 74, p. 391-406.

Fiske, R.S., Hopson, C.A., and Waters, A.C., 1963, Geology of Mount Rainier National Park, Washington: U.S. Geological Survey Prof. Paper 444, 93 p.

Free, M.R., 1976, Evidence for magmatic assimilation-in several diorites of the middle Columbia River Gorge: University of Utah, M.S. thesis, $65 \mathrm{p}$.

Hammond, P.E., 1974, Regional extent of the Stevens Ridge Formation in the southern Cascade Range, Washington: GSA Abstracts with Programs, v. 6 , p. 188 .

Hammond, P.E., 1980, Reconnaissance geologic map and crossections of southern Washington Cascade Range, latitude $45^{\circ} 30^{\prime}-47^{\circ} 15^{\prime}$ N., longitude $120^{\circ} 45^{\prime}$ $122^{0} 22.5^{\prime} \mathrm{W}$.: Dept. of Earth Sciences Publication, Portland State University, 31 p., 2 maps.

Hammond, P.E., Bentley, R.D., Brown, J.C., Ellingson, J.A., and Swanson, D.A., 1977, Volcanic stratigraphy and structure of the southern Cascade Range, Washington, in Brown, E.H., and Ellis, R.C., editors, Geological excursions in the Pacific Northwest: Bellingham, Washington, Western Washington University, p. 127-169.

Hol'daway, M.J., and Bussey, S., 1982, Mineralogy of the 01d Maid Flat geothermal exploratory hole no. 7A, Mount Hood, Oregon, in Geology and geothermal resources of the Mount Hood area, Oregon: Oregon Dept. of Geology and Mineral Industries, Special Paper 14, p. 57-76.

Palmer, L.E., 1977, Large landslides of the Columbia River Gorge, Oregon and Washington, in Choates, D.C., editor, Land-Slides: GSA Reviews in Engineering Geology, v. 3, p. 69-83.

Pope, R.J., 1972, Washington's Collins Point Slide between Wind and Dog Mountains at the Bonneville Lake: Lecture, The Geological Newsletter, p. 60-62. 
Schuster, J. Eric, and Korosec, Michael A., 1981, Preliminary report on heatflow drilling in Washington during 1981: Washington Department of Natural Resources Open File Report 81-8, November, 1981, 36 p.

Schuster, J. Eric, and Korosec, Michael A., Kaler, K, Bloomquist, R.G., Simpson, S., 1981, Geothermal Resources of Washington: Geologic llap GM-25, produced for the Division of Geothermal Energy, U.S. Dept. of Energy, scale 1:500,000.

Waters, A.C., 1973, The Columbia River Gorge: Basalt stratigraphy, ancient lava dams, and landslide dams, in Beaulieu, J.D., editor, Geologic field trips in northern Oregon and southern Washington: Oregon Department of Geology and Mineral Industries Bulletin 77, p. 133-162.

Williams, I.A., 1916, The Columbia River Gorge - its geologic history interpreted from the Columbia River Highway: Oregon Bureau of Mines and Geology, Mineral Resources of Oregon, v. 2, no. 3, $130 \mathrm{p}$.

Wise, W.S., 1961, The geology and mineralogy of the Hind River area, Washington, and the stability relations of celadonite: The lohns Hopkins University, Ph.D. thesis, $258 \mathrm{p}$.

Wise, W.S., 1970, Cenozoic volcanism in the Cascade Mountains of southern Washington: Washington Division of Mines and Geology Bulletin 60, 45 p. 


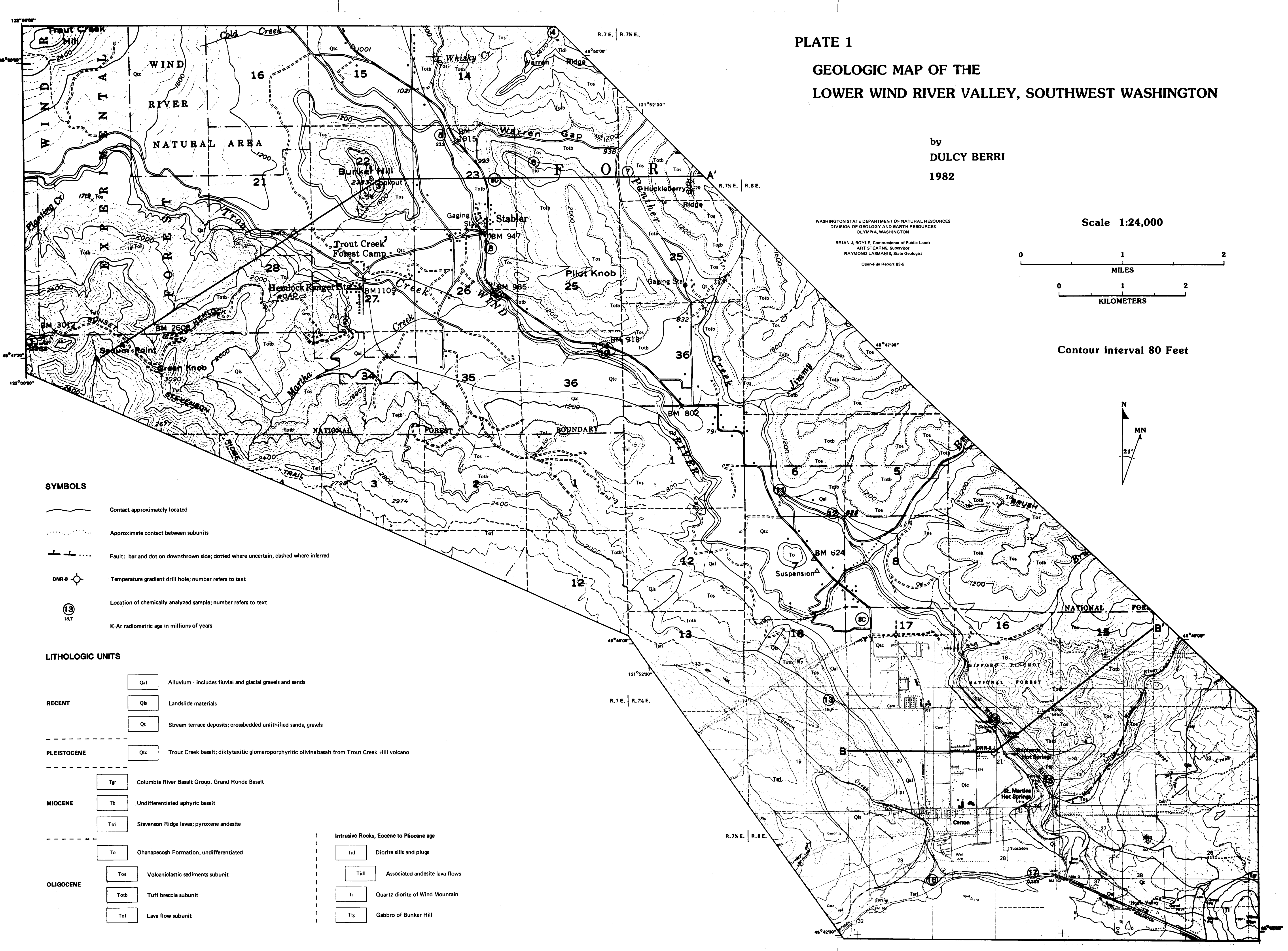


PLATE 2

GEOLOGIC CROSS SECTION

LOWER WIND RIVER VALLEY, SOUTHWEST WASHINGTON
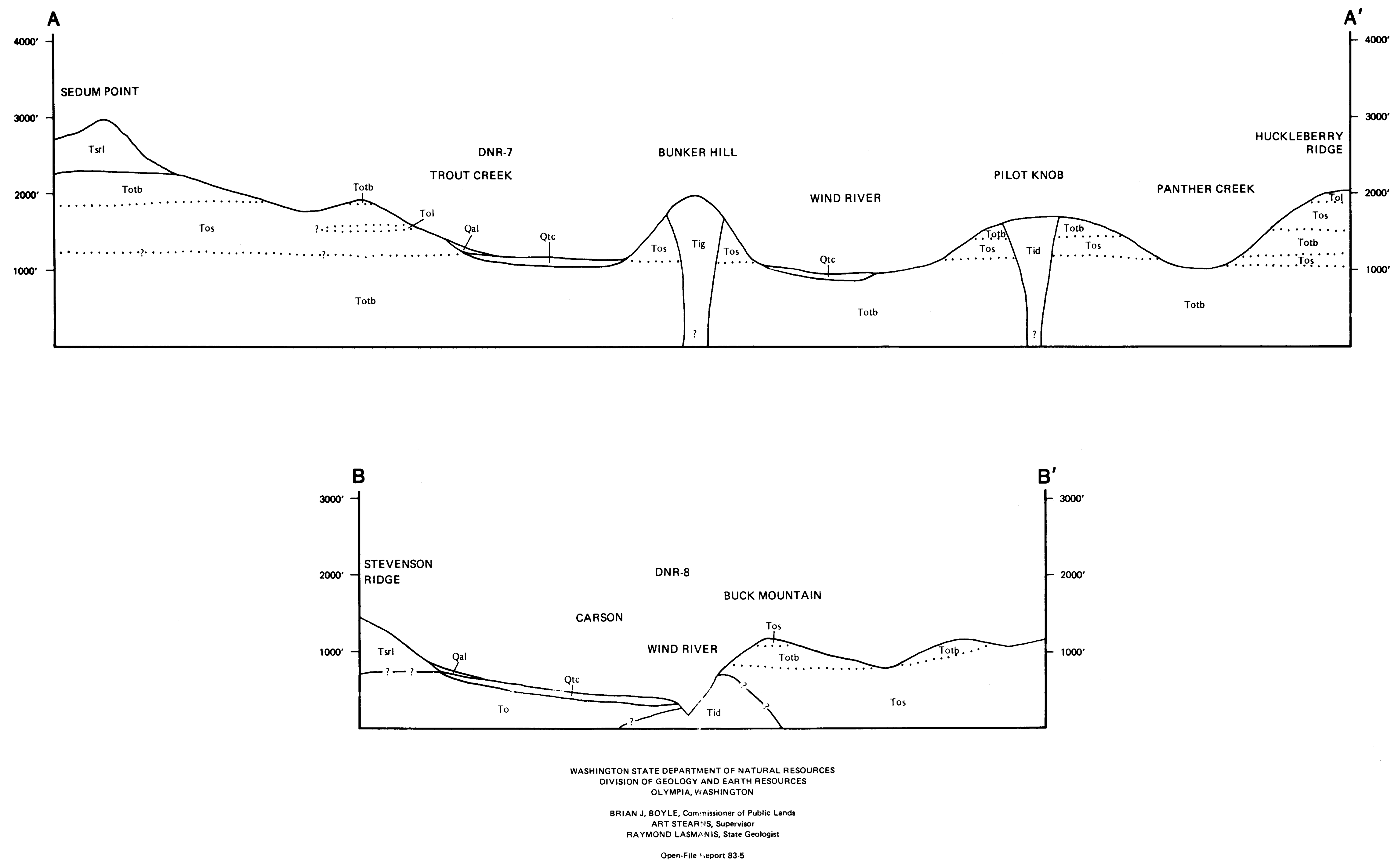

os 